Review

\title{
Review on Health Management System for Lithium-Ion Batteries of Electric Vehicles
}

\author{
Zachary Bosire Omariba ${ }^{1,2}$, Lijun Zhang ${ }^{1, *(1)}$ and Dongbai Sun ${ }^{1}$ \\ 1 National Center for Materials Service Safety, University of Science and Technology Beijing, \\ Beijing 100083, China; zomariba@egerton.ac.ke (Z.B.O.); dbsun@ustb.edu.cn (D.S.) \\ 2 Computer Science Department, Egerton University, Egerton 20115, Kenya \\ * Correspondence: ljzhang@ustb.edu.cn; Tel.: +86-10-6232-1017
}

Received: 15 April 2018; Accepted: 10 May 2018; Published: 15 May 2018

\begin{abstract}
The battery is the most ideal power source of the twenty-first century, and has a bright future in many applications, such as portable consumer electronics, electric vehicles (EVs), military and aerospace systems, and power storage for renewable energy sources, because of its many advantages that make it the most promising technology. EVs are viewed as one of the novel solutions to land transport systems, as they reduce overdependence on fossil energy. With the current growth of EVs, it calls for innovative ways of supplementing EVs power, as overdependence on electric power may add to expensive loads on the power grid. However lithium-ion batteries (LIBs) for EVs have high capacity, and large serial/parallel numbers, when coupled with problems like safety, durability, uniformity, and cost imposes limitations on the wide application of lithium-ion batteries in EVs. These LIBs face a major challenge of battery life, which research has shown can be extended by cell balancing. The common areas under which these batteries operate with safety and reliability require the effective control and management of battery health systems. A great deal of research is being carried out to see that this technology does not lead to failure in the applications, as its failure may lead to catastrophes or lessen performance. This paper, through an analytical review of the literature, gives a brief introduction to battery management system (BMS), opportunities, and challenges, and provides a future research agenda on battery health management. With issues raised in this review paper, further exploration is essential.
\end{abstract}

Keywords: lithium-ion batteries; electric vehicles; battery management system; electric power

\section{Introduction}

Lithium-ion batteries (LIBs) are one of the most promising technologies due to advantages like high efficiency, lower volume, small weight, temperature sensitivity, and maintenance [1-3]. They are the most ideal power source of the twenty-first century and have a bright future in many applications, such as portable electronic devices, electric vehicles (EVs) [4], aerospace systems, and power storage for renewable energy sources, like solar and wind turbines. However, there are many shortfalls, such as lack of safety, fragility, and aging, which may restrict the extensive use of LIBs. The consequences of battery failure can lead to catastrophes and inconveniences, which have turned to be popular and challenging issues [5], as reliability of LIBs is yet to be improved. However, determining the remaining useful life (RUL) of LIBs can aid to some level in curbing this problem [6,7].

There are many different techniques proposed in the literature that capture these crucial parameters to determine the battery state, to ensure that the battery delivers its specified output while optimizing the charge/discharge processes, and must be communicated to on-board systems. The battery management system (BMS) plays a significant role in the prediction of RUL for LIBs, as it acts as a connector between the battery and the EVs. The main goal of the BMS is three-fold: to protect 
the battery system from damage by detecting malfunctions, such as overcharge, excessive rise in temperature, and electric leak; to predict and increase the battery life; and to maintain the battery system in an accurate and reliable operational condition [8,9]. The BMS is a combination of sensors, controllers, communication, and computation hardware, with software algorithms designed to decide the maximum charge/discharge current and duration from the estimation of state-of-charge (SOC) and state-of-health (SOH) of the battery pack [10]. From this definition BMS performs the two main roles of monitoring the battery to determine information, such as $\mathrm{SOH}, \mathrm{SOC}$, and RUL, as well as to operate the battery in a safe, efficient, and non-damaging way [11-13].

In many industrial applications that make use of LIBs as one of the main power sources, the BMS has proven useful. The BMS contains a set of activities that monitor and perform $\mathrm{SOH}$, SOC, state-of-life (SOL), end-of-life (EOL), and state-of-power (SOP) estimation throughout the battery's entire life, and make a suitable decision to predict RUL. Thus, the BMS for LIBs is a decision process to intelligently perform maintenance, logistics, and system configuration activities on the basis of diagnostic and/or prognostics with the aim of producing actionable information to enable timely decisions [14] on maintenance optimization support, and reduce the costs of maintenance [7]. The BMS, therefore, implements state monitoring and evaluation, charge control, and cell balancing functionalities in order to maintain the safety and reliability of batteries [15]. Failure to perform these functionalities can result in battery failure, which can lead to reduced performance, operational impairment, and even catastrophic failure [16], making the performance of accurate prediction of RUL essential. RUL has attracted a great deal of interest from researchers and funding agencies around the world to mitigate the challenges associated with LIB use, in many high-impact applications, while protecting the environment.

There is a growing increase of EVs according to Bruen et al. [17], dependent on LIBs due to their numerous advantages, as compared to other batteries. This is further accelerated with the climate change concerns having a focus on a spotlight to EVs, and LIBs are believed to be the future to widespread EV adoption. However EVs are also faced with a number of drawbacks, as illustrated in Table 1, although technology is advancing fast to curb these challenges.

Table 1. Advantages and disadvantages of EVs from selected review papers.

\begin{tabular}{llll}
\hline & \multicolumn{1}{c}{ Advantages } & \multicolumn{1}{c}{ Disadvantages } \\
\hline- & Highly efficient & - & Electricity storage is still expensive \\
\hline- & Reduced emissions & - & Battery charging is time consuming \\
\hline- & High performance and low maintenance & - & $\begin{array}{l}\text { Primary resource depletion for some elements } \\
\text { of the LIB }\end{array}$ \\
\hline- & Very responsive and have very good torque & - & Range anxiety \\
\hline- & EV motors are quiet and smooth & - & Battery degradation costs \\
\hline- & Are more digitally connected than conventional vehicles & - & $\begin{array}{l}\text { Sufficient public charging infrastructure is } \\
\text { still lacking }\end{array}$ \\
\hline- & Simplified powertrain & - & Causes indirect pollution \\
\hline- & Low electricity consumption & - & Lacks the power to accelerate and climb quickly \\
\hline- & Good acceleration & Are heavy due to overloaded batteries \\
\hline$-\quad \begin{array}{l}\text { Can be charged overnight on low cost electricity } \\
\text { produces by any type of power station, } \\
\text { including renewables }\end{array}$ & & \\
\hline
\end{tabular}

(Source: [11,18-28]).

The BMS contains a portion responsible to monitor and control the $\mathrm{SOH}$ of a battery pack, and it is also referred to as the battery health management system (BHMS). However, according to Saha et al. [29], the BMS is a hardware designed to be a low-cost analog-to-digital data acquisition system. This hardware has three components: the signal conditioning board, the data acquisition board, and the embedded processor board. However, the BMS' main function is to monitor, control, 
and report the $\mathrm{SOH}$ of a battery. This review work will be a comprehensive collation of existing prognostic methods, and will provide convenience and inspiration for scholars to study and conduct further research. This review paper is organized into five sections. Section 2 talks about the BMS. Section 3 is about opportunities and challenges with respect to battery health and prognostics. Finally, Section 4 is about the critical future battery prognostic research work, and the conclusion are provided in Section 5.

\section{Health Management Systems for Batteries}

There is continuous increase in EV stock, but annual growth rates have been reducing consistently since 2011. In 2016 the EV stock growth was 59\%, down from 76\% in 2015, and 84\% in 2014, but statistics shows that battery electric vehicles (BEVs) still account for the majority of the electric car stock, at $60 \%$, as per the "Global EV Outlook 2017: Two Million and Counting" report [30]. According to this report the number of EVs increased from the previous report of a projection of one million EVs in 2016, to two million, projected in 2017. This trend shows that the number of EVs has been doubling over the years and this will put more pressure in the demand for LIBs, which has proved to be the main source of efficient power.

The current trend clearly demonstrates that with proper a BMS the number of BEVs will continue to rise, and LIBs are the main source of energy. This is because there are many aspects of the reliability process, such as requirement analysis, modelling and simulation, control strategy research, and online hardware testing of developing a BMS which requires a model to identify the characteristics of LIBs [31]. In recent years, a tremendous growth in sales of battery electric cars has been experienced and this puts more pressure on the battery technology. Table 2 shows the battery electric car stock by country, 2005-2016.

Table 2. Battery electric car stock by country, 2005-2016 (thousands).

\begin{tabular}{lcccccccccccc}
\hline & $\mathbf{2 0 0 5}$ & $\mathbf{2 0 0 6}$ & $\mathbf{2 0 0 7}$ & $\mathbf{2 0 0 8}$ & $\mathbf{2 0 0 9}$ & $\mathbf{2 0 1 0}$ & $\mathbf{2 0 1 1}$ & $\mathbf{2 0 1 2}$ & $\mathbf{2 0 1 3}$ & $\mathbf{2 0 1 4}$ & $\mathbf{2 0 1 5}$ & $\mathbf{2 0 1 6}$ \\
\hline Canada & & & & & & & 0.22 & 0.84 & 2.48 & 5.31 & 9.69 & 14.91 \\
\hline China & & & & & 0.48 & 1.57 & 6.32 & 15.96 & 30.57 & 79.48 & 226.19 & 483.19 \\
\hline France & 0.01 & 0.01 & 0.01 & 0.01 & 0.12 & 0.30 & 2.93 & 8.60 & 17.38 & 27.94 & 45.21 & 66.97 \\
\hline Germany & 0.02 & 0.02 & 0.02 & 0.09 & 0.10 & 0.25 & 1.65 & 3.86 & 9.18 & 17.52 & 29.60 & 40.92 \\
\hline India & & & & 0.37 & 0.53 & 0.88 & 1.33 & 2.76 & 2.95 & 3.35 & 4.35 & 4.80 \\
\hline Japan & & & & & 1.08 & 3.52 & 16.13 & 29.60 & 44.35 & 60.46 & 70.93 & 86.39 \\
\hline Korea & & & & & & 0.06 & 0.34 & 0.85 & 1.45 & 2.76 & 5.67 & 10.77 \\
\hline Netherlands & & & & 0.01 & 0.15 & 0.27 & 1.12 & 1.91 & 4.16 & 6.83 & 9.37 & 13.11 \\
\hline Norway & & & 0.01 & 0.26 & 0.40 & 3.35 & 5.38 & 9.55 & 19.68 & 41.80 & 72.04 & 98.88 \\
\hline Sweden & & & & & & & 0.18 & 0.45 & 0.88 & 2.12 & 5.08 & 8.03 \\
\hline United Kingdom & 0.22 & 0.55 & 1.00 & 1.22 & 1.40 & 1.65 & 2.87 & 4.57 & 7.25 & 14.06 & 20.95 & 31.46 \\
\hline United States & 1.12 & 1.12 & 1.12 & 2.58 & 2.58 & 3.77 & 13.52 & 28.17 & 75.86 & 139.28 & 210.33 & 297.06 \\
\hline Others & & & & & 0.64 & 0.80 & 3.17 & 5.83 & 10.60 & 19.43 & 36.20 & 52.41 \\
\hline Total & $\mathbf{1 . 3 7}$ & $\mathbf{1 . 7 0}$ & $\mathbf{2 . 1 6}$ & $\mathbf{4 . 5 4}$ & $\mathbf{7 . 4 8}$ & $\mathbf{1 6 . 4 2}$ & $\mathbf{5 5 . 1 6}$ & $\mathbf{1 1 2 . 9 5}$ & $\mathbf{2 2 6 . 7 9}$ & $\mathbf{4 2 0 . 3 4}$ & $\mathbf{7 4 5 . 6 1}$ & $\mathbf{1 2 0 8 . 9 0}$ \\
\hline & $($ Source: Global EV Outlook 2017 report: two million and counting [30]). & &
\end{tabular}

Due to the promising growth in sales of battery-powered cars, there is an increased research interest towards the BMS of LIBs. This is attributed to the need of models and technologies for accurate estimation of a battery's RUL for different high-impact applications, including mobility applications in EVs [32]. Additionally, LIBs are the most promising power source for EVs due to their numerous benefits, like being lightweight, their high energy density, and relatively low self-discharge compared to 
nickel-cadmium (NI-cad) and NiMH batteries [33,34]. Battery health management and RUL estimation are performed in order to ascertain the current and previous battery states and to predict the future state and RUL.

The BMS is a hardware and software system that is in charge of battery protection and $\mathrm{SOH}, \mathrm{SOC}$, and state-of-function (SOF) estimation [6,35]. The key performance parameters tradeoffs, like safety, life span, performance, charging time, and cost, are managed by the BMS. Among those, an accurate quantification of the battery state is one of the most critical tasks for the BMS, along with the task of supervising lithium-ion cells when they are used in large battery packs [10]. In LIB systems, the BMS is used to maintain safety specifications of the battery system by ensuring that each cell is equally charged and voltage balance exists in the battery pack [36]. This means that a reliable BMS is crucial; otherwise the LIBs can move into the danger zone below the threshold area, which can be catastrophic, or lead to reduced performance.

\subsection{Battery Terminologies}

RUL: RUL is the remaining time or number of load cycles that the battery has during which it will be able to meet its operating requirements $[6,7,37]$, or it is simply the length of time from the present time to the end of life [38]. RUL has attracted major emphasis in research and manufacturing vehicles' BMS so as to meet the requirement of reduced costs, increased accuracy and reliability, and avoidance of catastrophic failure. RUL can be computed as:

$$
\mathrm{RUL}=T_{f}-T_{\mathcal{C}}
$$

where $T_{f}$ is a random variable of time of failure when degradation is detected, and $T_{C}$ is the current time when the predicted signal passes the failure time with some confidence to show uncertainty of the prediction [14]. The different sources of uncertainty, however, must be propagated together with the confidence of prediction and RUL estimation, since inherent uncertainties of the degradation process, measurements, environmental/operational conditions, and modeling errors exist.

SOC: SOC represents the available capacity and is one of the most important states that needs to be monitored to optimize the performance and extend the lifetime of the batteries [6]. The battery SOC is an expression of the present battery capacity as a percentage of the maximum capacity. SOC is estimated according to such conditions as working current, temperature, and voltage [39]. The SOC is generally calculated using the current integration to determine the change in battery capacity over time. If we consider a completely discharged battery, with $I_{b}(\tau)$ as the charging current, the charge delivered to the battery is $\int_{t_{0}}^{t} I_{b}(\tau) d \tau$. The SOC of the battery is simply expressed as:

$$
\operatorname{SOC}(t)=\frac{\int_{t_{0}}^{t} I_{b}(\tau) d \tau}{Q_{0}} \times 100 \%
$$

as the charging current, the charge where $Q_{0}$ is the battery capacity at time $t$. According to Saxena et al. [40] estimation of SOC is, by far, the most popular approach where charge counting or current integration is used in different ways to estimate battery capacity. This makes SOC estimation the most important approach in battery management since it represents the available battery capacity, which enables performance optimization and extension of battery lifetime [6]. BMS prevents the battery from discharging below a certain SOC and charging when it is full [41]. From specifications of EV batteries, as shown in Table 3, the safety range for charging and discharging is about $-20^{\circ} \mathrm{C}$ to $60{ }^{\circ} \mathrm{C}$.

DOD: The depth-of-discharge (DOD) is the percentage (\%) of the battery capacity that has been discharged, expressed as a percentage of maximum capacity. A discharge of at least $80 \%$ DOD [42], is referred to as deep discharge, and many studies assume a fixed cycle lifetime. This is a strong 
simplification of reality as a traction battery will not be fully discharged every single time until the allowed minimum SOC of $20 \%$. The battery DOD is given by the equation:

$$
\operatorname{DOD}(t)=1-\operatorname{SOC}(t)=\frac{Q_{0}-\int_{0}^{t} I_{b}(\tau) d \tau}{Q_{0}} \times 100 \%
$$

It is common that when the DOD is higher the shorter the cycle life. To achieve this higher cycle life, a larger battery can be used for a lower DOD during normal operations [10].

$\mathrm{SOH}$ : The $\mathrm{SOH}$ is a function of depth-of-charge, and is defined as the ratio of the maximum charge capacity of an aged battery to the maximum charge capacity when the battery is new [10]. The indicator that the battery capability to store energy is deteriorating, and decreases over the battery lifetime, is the measured $\mathrm{SOH}$ [6]. The BMS of EVs ensures that the battery cells charge within the safety ranges. $\mathrm{SOH}$ is tracked by measuring the internal resistance, since the internal resistance increases as the capacity increases. The $\mathrm{SOH}$ is computed as:

$$
\mathrm{SOH}=\frac{Q_{a c t}}{Q_{R}} \times 100 \%
$$

where $Q_{R}$ is the rated capacity and $Q_{a c t}$ is the actual battery capacity.

EOL: Prognostics are focused on predicting when a fault, damage, or wear of a component, subsystem, or system will progress to a point that is deemed unsafe, or which a system will not function as specified $[43,44]$. This time point is called EOL, and the time remaining until that point is reached is known as RUL [45]. At the EOL the system value of performance is deemed to be unreliable, or can lead to failure of the EVs. When the battery usage cycle reaches the EOL, the prediction accuracy increases, and prediction variance gradually decreases [32].

Table 3. Specifications of EVs LIB.

\begin{tabular}{cc}
\hline Energy density $(\mathrm{W} / \mathrm{Kg})$ & 72 to 200 (chargeable electric energy per weight of battery pack) \\
Nominal voltage & $3.7 \mathrm{~V}$ \\
Power density & 1800 (proportion of dischargeable electric energy to charged energy) \\
Very low \\
Cyercharge tolerance & 500 to 1000 (Number of charge $/$ discharge cycles in battery's entire life) \\
Cycle life & $-20{ }^{\circ} \mathrm{C}$ to $60{ }^{\circ} \mathrm{C}$ \\
85 to $98 \%$ \\
Operating rate of temperature & $500-2500 \$ / \mathrm{kWh}$ \\
Energy efficiency & 5 to 15 years \\
Energy cost & High energy cost $/$ safety \\
Lifetime &
\end{tabular}

(Source: $[46,47])$.

EOD: End-of-discharge (EOD) is the reading of the lower battery capacity that is occasioned by the energy loss that occurs inside the battery, and a drop in the voltage that causes the battery to reach the low-end voltage cut-off sooner. EOD means the battery is empty under discharge, and that the SOC should be $0 \%$. It can be an absolute voltage level or a variable which is compensated by loading. The prediction of EOD times for a battery has been investigated recently, to predict the time when a predefined cut-off threshold voltage is reached and the power source is no longer available [40], thus indicating that the battery pack has run out of charge [29].

\subsection{Architecture of the BMS}

The architecture of the BMS comprises both the hardware and software parts. This system is built to control the operational conditions of the battery to prolong its life, guarantee its safety, and provide an accurate estimation of different states of the battery for the energy management modules [6] at all battery states, whether it is in use or not, during charging/discharging. Consequently, the BMS 
improves battery security, reliability, and prevents overshooting and overcharge, while optimizing the performance of EVs. To meet this, the hardware architecture of the BMS for LIBs comprises six components, namely: cell monitoring (e.g., temperature, charge/discharge monitoring); passive/active cell balancing; current measurement; contactor and interlock control and monitoring; isolation monitoring; and communication interfaces to peripherals and the environment [13]. The software structure of the BMS consists of four functionalities to aid in state determination, power capability prediction, load balancing, and safety monitoring [2]. All of these tasks are run by the BMS controller, which also extracts high-level battery pack information from the individual cell within the pack, and serves as an interface between the battery pack and the vehicle system controller [48].

\subsection{Stages of Performing BMS}

In relation to battery management, the functional tree of a state-of-the-art BMS for large lithium-ion battery packs, as shown in Figure 1, consists of five main stages. Each phase performs a unique task from each other, but in a coordinated way to guarantee the overall objective of performing an efficient management of battery health. There are five main stages of performing BMS: condition monitoring, hazard protection, charge/discharge management, diagnosis, and data management and assessment, as explained below. Freischer et al. [49] captured all of these main stages, as shown in Figure 1, in their functional tree of a state-of-the-art BMS for large LIB packs. As a tree with one stem, but many branches and leaves, battery management contains five components, as shown in the functional state-of-the-art BMS for large LIB packs, but these components are broken down into smaller units. It starts with monitoring the battery conditions and extends to data management, which aids the decision-making process about the batteries. The batteries' overall state can reflect the kind of action to be taken, which includes regular maintenance checks. Any BMS product chosen must provide most of the functions identified in the functional tree in Figure 1.

\subsubsection{Condition Monitoring}

The BMS's first main function is to monitor measurable states of the battery, like pack voltage and current, cell voltage, temperature, isolation, and interlocks [50]. Data from battery states are collected at regular intervals through a procedure of monitoring carefully-selected physical parameters, which indicate the health condition or state of the equipment under given profiles [14]. The battery conditions can be influenced by both internal and external parameters, like temperature and vibrations. The literature shows that vibration load and temperature influences performance of LIBs, leading to a significant decrease in cell capacity, and deterioration inconsistencies [51]. Whenever any abnormal conditions, such as over-voltage or overheating, are detected, the BMS should notify the user and execute the preset correction procedure. In addition to these functions, the BMS also monitors the system temperature to provide a better power consumption scheme, and communicates with individual components and operators [15].

\subsubsection{Hazard Protection}

The battery is protected against hazards by first defining the system settings which can predict events that are hazardous. The hazards can be as a result of undercharge, overcharge [9], rise in temperature, and other unforeseen factors. The BMS monitors the battery state and the obtainable measurement data can be used to detect or predict these events, which are either internal or external. Timely response to hazardous events can be achieved through running of fault tolerance routines, cooling/heating management, interlock loop management, and external communication. The BMS should contain accurate algorithms to measure and estimate the functional status of the battery and, at the same time, be equipped with state-of-the-art mechanisms to protect the battery from hazardous and inefficient operating conditions [50]. Therefore, it is of importance to identify and quantify substances being released from the battery during tests representing misuse and abuse events, and to ensure that the amounts released are not hazardous to vehicle occupants and first aid responders [52]. 


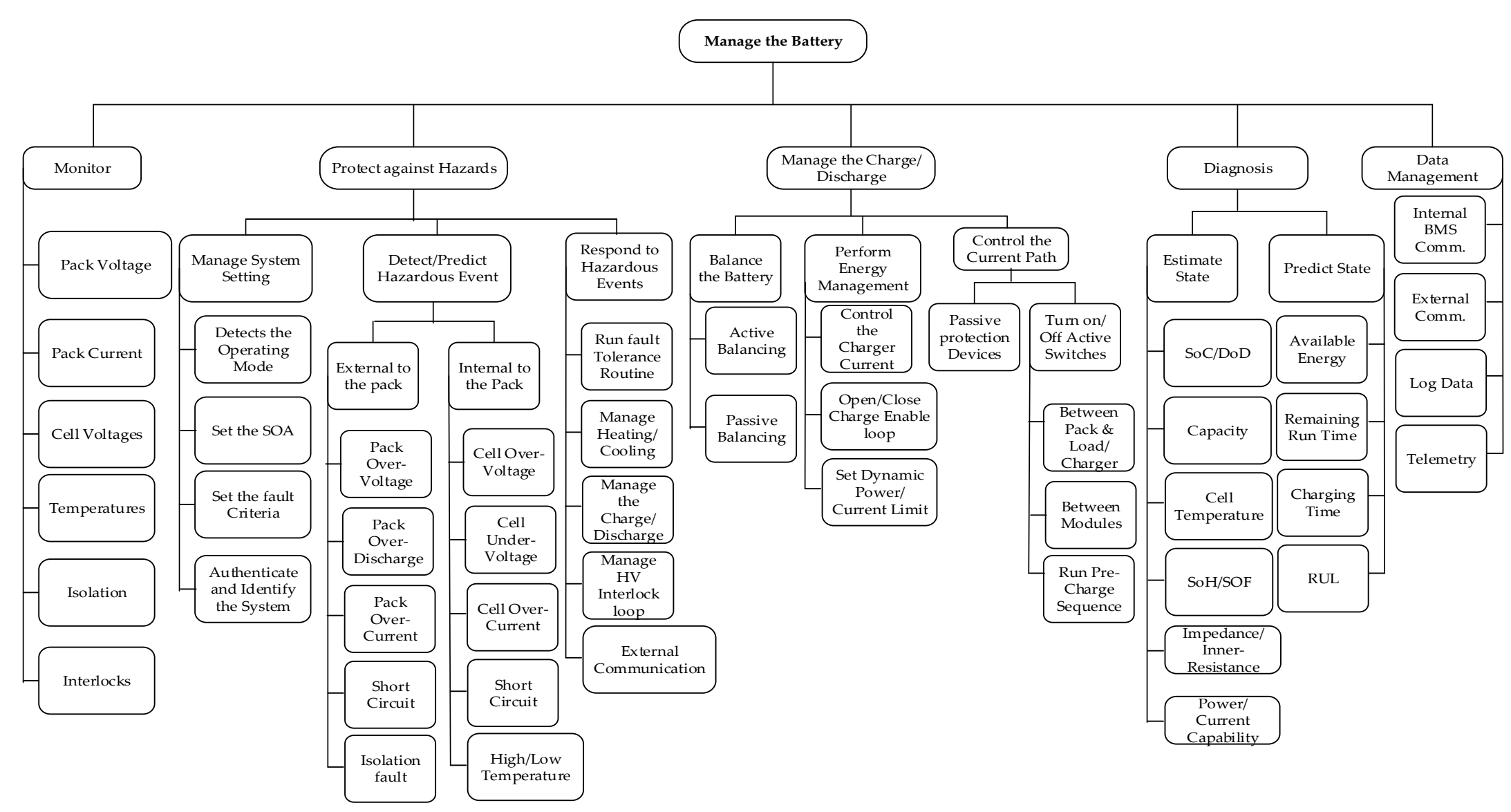

Figure 1. Functional tree of a state-of-the-art BMS for large LIB packs (Reproduced with permission from [49], Copyright Publisher, 2016). 


\subsubsection{Charge/Discharge Management}

The requirements of electrified vehicles brought up the challenge in the charge/discharge rate, making battery degradation during charge/discharge optimization extremely important. The charge/discharge starts when the demanded power crosses the threshold, and is evaluated per unit time, and according to [53] cell balancing equalizes the voltage on each cell of the battery pack. This constitutes three major sub-functions for current control, energy management, and battery balancing. The current path is controlled by employing passive protection devices, or by turning on/off active switches between the pack and load/charger, between modules, and running of a pre-charge sequence. On performing energy management the charger current is controlled, as well as opening/closing the charge-enable loop, and sets the dynamic power of current limits. At the same time battery balancing is achieved through active/passive balancing to equalize the states of cell charge. Since the main energy source of EVs is the battery, it is very crucial to have proper battery protection during charge and discharge. More so, when the EVs are travelling long distances, it is proper to predict the remaining driving distance, as this usually involves discharge of up to $80 \%$ or more. Consequently, if batteries are discharged in brine, their initial voltage will be above the electrolysis voltage of water, and hydrogen gas will be produced, thus requiring ventilation to avoid an explosion. If discharged by a resistor the current must be kept low enough so that the batteries do not overheat [54].

\subsubsection{Diagnosis}

Battery health diagnosis is the process of monitoring the underlying degradation to be able to track the actual performance and take countermeasures if developing faults occur [55]. In this phase the battery states are mainly estimated or predicted based on capacity, cell temperature, charge/discharge time, impedance, and power. This diagnostic mode helps to determine or predict the RUL or to observe safe and reliable battery operation while aging. The diagnosis contains functions to estimate and predict battery states. Therefore, information is used, on the one hand, to observe the safe operation of the battery while aging and, on the other hand, to perform complex algorithms, e.g., for a range estimation in EVs [2]. When a component suddenly fails and the system cannot perform its functions, maintenance actions are automatically carried out to restore the system to working order [56]. Various techniques, such as electrochemical impedance spectroscopy, slow rate cyclic voltammetry, differential thermal voltammetry, incremental capacity (IC) and differential voltage (DV) could identify and quantify degradation modes in real-time applications and could be suitable for implementation within the BMS [57].

\subsubsection{Data Management and Assessment}

Data are important sources of information to build prognostics models, but accuracy of prognostics suffers from inherent data uncertainties. This is attributed to factors, like lack of sufficient data, sensor noise, and unknown environmental and operating conditions, together with engineering variations [14]. Thus, the battery system data are managed in order to make decisions or take actions which can deter system failures or which can lead to catastrophes. This is achieved by internal or external communication that involves human and machine. The algorithm that performs all the tasks is shown in Figure 2.

There are various indirect methods that propose connecting the measured battery parameters (voltage, current, and temperature) with the battery SOC employing a battery model. A high-fidelity battery model is required to capture the characteristics of the real-life battery and predict its behavior under a wide variety of conditions. In the BMS state estimation algorithm, using the parameters as model inputs, the model can be used to calculate the SOC, and other states of the battery [6] and, therefore, determines the battery's more critical states [58]. A great deal of research is being done to improve the performance of estimation algorithms, as shown in Figure 2. 


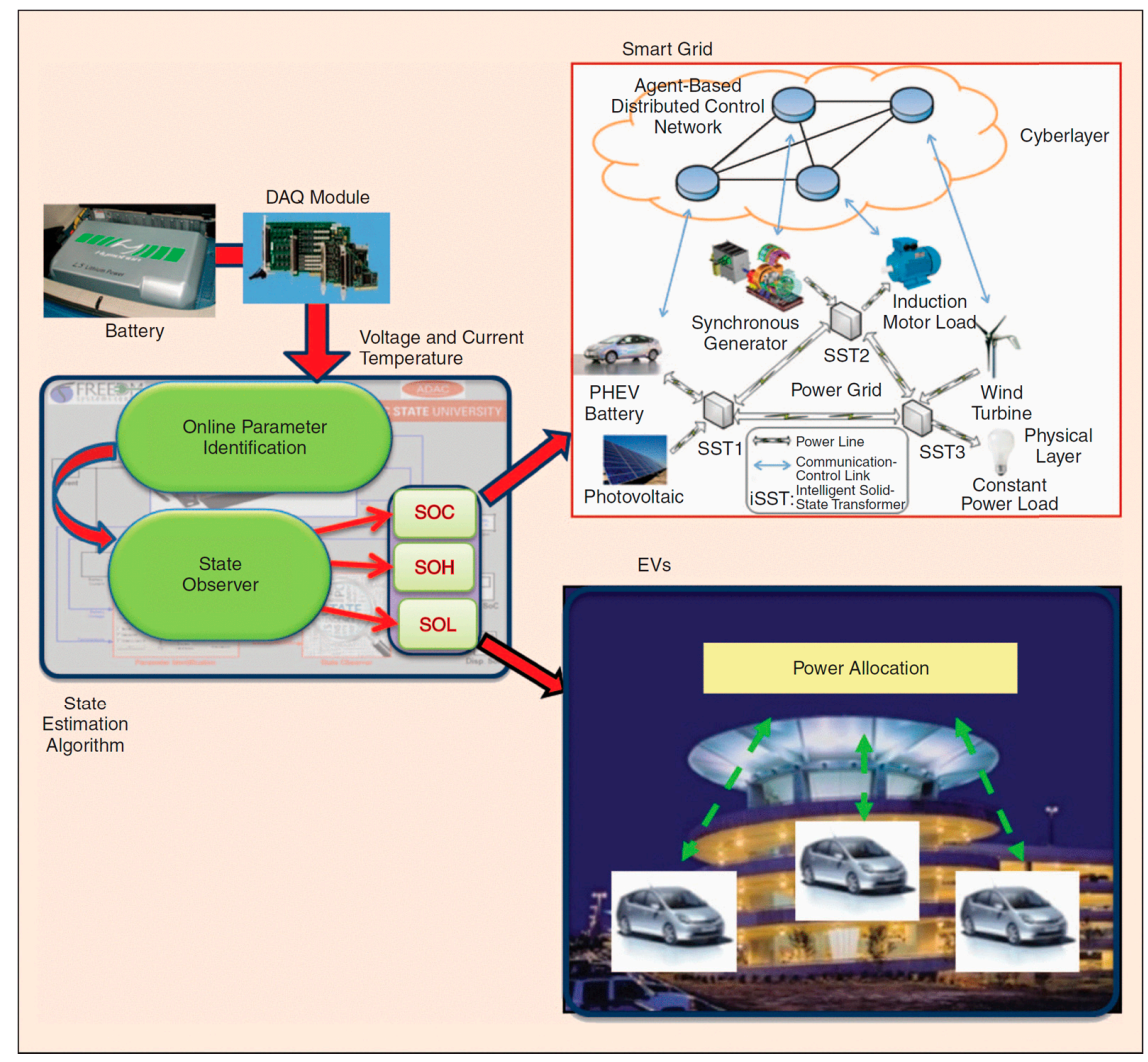

Figure 2. Battery management algorithms function in both the smart grid and EVs (Reproduced with permission from [50], Copyright Publisher, 2013).

The battery parameters are captured through online parameter identification. The BMS calculates the percentage of the cell health, by monitoring the cell internal resistance, together with tracking down the weakest cell in the battery pack. The user is, therefore, provided with the information on the overall SOH of the battery pack. This demonstrates the internality of the BMS in the EVs. The EVs receive their power from the centralized power allocation system, which ensures that every vehicle's battery pack is charged to full capacity before it starts its operations. The smart grid (SG) contains various power sources, like the plug-in hybrid electric vehicle (PHEV) battery, synchronous generator, photovoltaic cell, constant power load, and wind turbine.

The emergence of the SG presents the next generation of electrical power systems, and will enable residents to have the opportunities to manage their home energy usage and reduce expenditures on energy [59]. This is due to considering sustainable development and the crisis of energy, and renewable energy production becomes an important factor in the electricity generation system. The power load data is communicated through the cyber layer, which is an agent-based distributed control network. However, if kinetic energy generated when the vehicle is in motion is transformed into charging the battery, then a great deal of savings can be made on the side of power usage, and efficiency can be improved.

\subsection{Issues of the BMS}

The hardware and software of the BMS have various issues that have to be addressed in order to meet the demand for secure and safe usage of LIBs. For an ideal BMS and its development process, several issues arise that must be taken into consideration seriously during the design of the BMS. These issues are illuminated below. 


\subsubsection{Diversity of Battery Management Applications}

There are a diverse number of battery management applications. These applications include applications for monitoring of battery tests, evaluation of various state diagnosis and state predictions, rapid assembly of battery system demonstrators, tests for new sensor technologies, like sensor-less temperature measurement, etc. [60]. This variant in battery management applications calls for the development of a modular and flexible BMS. The modularized balancing system should have different equalization systems that operate inside and outside of the modules [8].

\subsubsection{Handling of Potential, but Unprecedented, Hazards}

LIB cells need to be monitored continuously. To maintain the safety and reliability of battery cells and the safety of people, the use of battery systems is of great use. However, some unprecedented hazards may occur which may turn out to be catastrophic. There is a missing literature on the safety analysis of the hazards of opening lithium batteries, and how discharging them mitigates these hazards. The main safety hazard of opening LIB in air is the exothermic reaction of lithium ions or lithium metal (if present) with oxygen. Opening in water results in an exothermic reaction and the generation of hydrogen gas, which is explosive [54]. Since damaged cells cannot be safely opened, this calls for recycling. Another safety hazard is discharging of the batteries themselves. If the batteries are discharged in brine, their initial voltage will be above the electrolysis voltage of water and hydrogen and oxygen gases will be produced. These gases must be ventilated to avoid an explosion. If the batteries are discharged by a resistor the current must be kept low enough so that the batteries do not overheat.

Some spent batteries are classified as hazardous wastes, increasing transportation, treatment, and disposal costs, as well as the effort needed to achieve regulatory compliance [61]. These hazards form the major function of the BMS to protect the battery against hazardous situations, while maintaining each cell of the battery within its safe and reliable operating range. However, despite the hazardous nature of spent LIBs, they also contain valuable metals, such as copper, aluminum, and cobalt with commercial potential, and the increased mining of natural ores for these metals is leading to shortages, creating a market for recycled LIBs $[62,63]$.

\subsubsection{Lack of Safe Operating Areas for Specific Battery Cells}

Due to the continuous change of both the internal and external environment for the batteries, there is no single existence of a safe operating area for specific battery cells. When cells are connected in series, some discrepancies in cell internal resistance and differences in cell capacity may occur, and might lead to cell overcharging or undercharging. This inconsistency leads to unreliability and unstable efficiency of the cells, and this poses a serious problem. To solve this problem cell balancing can be used to achieve long battery life and to ensure reliability and safety $[60,64,65]$. Two types of algorithms are used in cell balancing: voltage-based algorithm and state of charge-based balancing algorithms [66]. The BMS is imperative for active or passive balance circuits to overcome any inconsistency problems among the serially-connected cells [67]. Therefore, it is required that the BMS is designed and developed to take control of the unending control of the change of environment that is sometimes unpredictable.

\subsubsection{Ensuring an Efficient Operational State of the Peripheral Control Units and the} Power Converters

Since the meaningful hardware and electrochemical properties of the battery cells are impacted by many diverse factors, it is difficult to ensure an efficient operational state of the peripheral control units $[60,68]$. This will, consequently, impact the design and development of the BMS for EVs. Prognostics, themselves, are useful because they supply the decision-maker with an early warning about the expected time to system/subsystem/component failure and let them decide the appropriate 
actions to deal with the failure. The benefit from prognostics can flourish if its information is used as the main source of system health management. The BMS not only controls the operational conditions of the battery to prolong its life and guarantee its safety, but also provides accurate estimation of the $\mathrm{SOC}$ and $\mathrm{SOH}$ for the energy management modules in the smart grid and EVs. To fulfill these tasks, a BMS has several features to control and monitor the operational state of the battery at different battery cell, battery module, and battery pack levels [50].

\subsection{Prognostic Methods}

Prognostics and health management (PHM) is a set of activities that monitor and estimate the system's SOH throughout its entire life and take suitable decisions at favorable times to extend the system's RUL [69]. Prognostics, itself, are useful because they supply the decision-maker with an early warning about the expected time to system/subsystem/component failure and let them decide the appropriate actions to deal with this failure [70]. The benefits from prognostics can flourish if their information are used as the main source for system health management. The least mature element, and chief component of PHM, are prognostics, which attempt to estimate the RUL of a component when a given abnormal condition has been detected [71]. The key factor is to estimate the RUL, as well as assess the confidence estimate. This makes a prognostic failure a relatively recent area of research to which the scientific community is beginning to give increasing importance, contrary to diagnostics [56,72].

Various factors, like storage voltage, internal and external battery temperatures, rate of discharge, depth-of-discharge, vibrations, etc. [73], must be taken into account when performing battery capacity degradation monitoring. According to $\mathrm{Wu}$ et al. [74], this LIB degradation is a nonlinear and time-varying dynamic electrochemical process, and in-depth mechanism analysis is clear in physical significance and concepts. It involves a large number of parameters and complex calculations for accurate modelling making it unsuitable for real-time monitoring and accurate modeling. The capacity degradation of LIBs is often used as a health indicator to establish degradation models. LIB failure, however, occurs when the capacity drops below a normal capacity value or failure threshold value [75]. To perform this task for safe and reliable use of LIBs [76], there are basically three methods classified as physical methods, data driven methods, and hybrid methods that are used to realize an accurate BMS. The summary of these methods is illustrated in Table 4.

Table 4. Summary of prognostics methods.

\begin{tabular}{|c|c|c|c|}
\hline $\begin{array}{l}\text { Prognostic } \\
\text { Approaches }\end{array}$ & Categories of Approaches & Pros & Cons \\
\hline $\begin{array}{l}\text { Physical } \\
\text { Approaches } \\
([5,6,37])\end{array}$ & $\begin{array}{l}\text { Electrical Circuit Model-Based } \\
\text { Estimation (ECM) and } \\
\text { Electro-chemical Model-Based } \\
\text { Estimation (EChM) }\end{array}$ & $\begin{array}{l}\text { - } \quad \text { Gives accurate predictions of the } \\
\text { temperature distribution } \\
\text { - } \quad \text { Shows better performance } \\
\text { - } \quad \text { Simplicity }\end{array}$ & $\begin{array}{l}\text { - The test has to be conducted } \\
\text { under exact conditions } \\
\text { - Some measurements must be } \\
\text { conducted via invasive operation } \\
\text { - Some instruments cannot be } \\
\text { utilized into real application } \\
\text { - Hard to identify the parameters in } \\
\text { the model } \\
\text { Parameters may change along } \\
\text { with the working condition. }\end{array}$ \\
\hline \multirow{2}{*}{$\begin{array}{l}\text { Data-based } \\
\text { Approaches } \\
([6,72,74])\end{array}$} & Machine Learning Approaches & 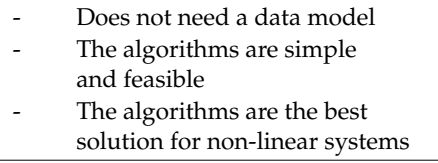 & $\begin{array}{l}\text { - The point estimated value of RUL } \\
\text { - Does not describe the uncertainty } \\
\text { of measurement results }\end{array}$ \\
\hline & Filtering Approaches & $\begin{array}{l}\text { - } \quad \text { Can be used in any form of } \\
\text { state-space model } \\
\text { Best solution for non-linear, } \\
\text { Gaussian, and } \\
\text { non-Gaussian systems }\end{array}$ & $\begin{array}{ll}\text { - } & \text { Needs data mode } \\
\text { (state-space model) } \\
\text { - } \quad \text { The point estimated value of RUL }\end{array}$ \\
\hline
\end{tabular}


Table 4. Cont.

\begin{tabular}{|c|c|c|c|}
\hline $\begin{array}{l}\text { Prognostic } \\
\text { Approaches }\end{array}$ & Categories of Approaches & Pros & Cons \\
\hline & Stochastic Approaches & $\begin{array}{l}\text { - } \quad \text { Considers the time-dependence of } \\
\text { the degradation process } \\
\text { - } \\
\text { Describes the uncertainty of } \\
\text { predictable results }\end{array}$ & $\begin{array}{l}\text { - } \quad \text { Higher calculation complexity } \\
\text { - } \quad \text { Considers uncertain factors }\end{array}$ \\
\hline $\begin{array}{c}\text { Hybrid } \\
\text { Approaches } \\
{[26,77-82]}\end{array}$ & Series/Parallel Approach & $\begin{array}{l}\text { - Achieves higher accuracy than } \\
\text { conventional methods } \\
\text { - Increases process reliability } \\
\text { and robustness }\end{array}$ & $\begin{array}{l}\text { Reliability is valid only for given } \\
\text { conditions and a period of time. }\end{array}$ \\
\hline
\end{tabular}

\subsubsection{Physical Methods}

The physical method is also called the model-based method. It comprises of an electrical circuit model-based estimation (ECM) method, and an electrochemical circuit model-based estimation (EChM) method. In the ECM discrete-time identification methods are less robust due to undesired sensitivity issues in the transformation of discrete domain parameters. This method promises simplicity by way of enabling easy implementation on a low-cost target microcontroller. It shows better performance in a low SOC range compared with one that uses average SOC in the ECM. The battery's nonlinear dynamic behavior identification could increase significantly as this method is quite accurate. When it comes to temperature distribution through the cell surface, and the behavior under various operating conditions, the ECM gives accurate predictions as it could be used in enhanced SOC estimation procedures.

The EChM includes dependence of the battery behavior on SOC and temperature. However excess temperature can greatly accelerate the battery aging process and even cause fire or explosion in the battery pack under severe cases. The tests are to be conducted under exact conditions despite the same measurements being conducted under invasive operations. The parameters are difficult to be identified in this model, as they change along with working conditions. In general the battery degradation increases if it is kept at a high SOC. Currently, countries and vehicle manufacturers are announcing aggressive targets for completely phasing out internal combustion engines, and EVs will get a great boost [83].

\subsubsection{Data-Based Methods}

The data-driven prognostics typically require sufficient offline training datasets for accurate remaining useful life for engineering products [84]. Data-based approaches of battery modeling use the battery's $\mathrm{SOH}$ data, which can be measured through advanced sensor technology to extract effective feature information, and construct the degradation model to predict RUL [74]. The data-based models are based on three methods, namely, machine learning or artificial intelligence (AI), filtering, and stochastic approaches. The machine learning method is a probabilistic method meant to improve the performance of estimation algorithms. There are four approaches under this algorithm, namely, particle swarm optimization (PSO), genetic algorithm-based estimation (GA), fuzzy-based neural networks (ANFIS), and fuzzy logic-based estimation (FL). The AI method does not need a data model, is simple, feasible, and is the best solution for non-linear systems [37], but this method does not describe the uncertainty of measurement results.

The filtering technique is used in any form of space model and is the best solution for non-linear, Gaussian, and non-Gaussian systems. However, this model needs a data model (state-space model). On the other hand, the stochastic technique is desired because it describes the uncertainty of the predictable results and considers the time dependence of the degradation process. However, this approach involves calculation complexity, and considers uncertain factors. The main advantage of this approach is its precision, since the predictions are achieved based on a mathematical model of the degradation. However, the derived degradation model is specific to a particular kind of component or material and, thus, cannot be generalized to all the system's components. In addition to this, obtaining a mathematical model of degradation is not an easy task and needs well-instrumented test 
benches, which can be expensive [85]. The advantage of using a data-driven prognostic approach is its applicability, cost, and implementation.

\subsubsection{Hybrid Methods}

This method constitutes the series and parallel approaches. This method is usually based on combining various physical and data-based approaches to leverage the strengths from both categories. This method proves to be exhibiting more strength than its predecessors since it narrows down their weaknesses. Thus, this method increases process reliability and robustness by combining the complementary information from different prognostic methods in intelligent ways compared to a single model-based method $[77,78,81,82]$. However, this method has a limitation of offering reliable validity only for certain given conditions and periods of time. These benefits of hybrid methods explain why it is gaining popularity compared to its counterparts.

\subsection{Battery Management System Framework}

Figure 3 is an elaborate basic framework with descriptions of the software and hardware of the BMS of EVs. The hardware component is embedded into the EV equipment, and is coupled with instructions on how to perform certain basic operations to ensure smooth running of EVs. This system will send signal warnings to the driver and risk responders whenever they sense some element of danger so that the necessary action can be taken. Close monitoring and frequent maintenance operations for this kind of system is crucial, so that any eventuality can be countered well in advance. The BMS achieves this by rigorously opening the contactors in the case of harsh limits violations to prevent the battery operating beyond its limits [12].

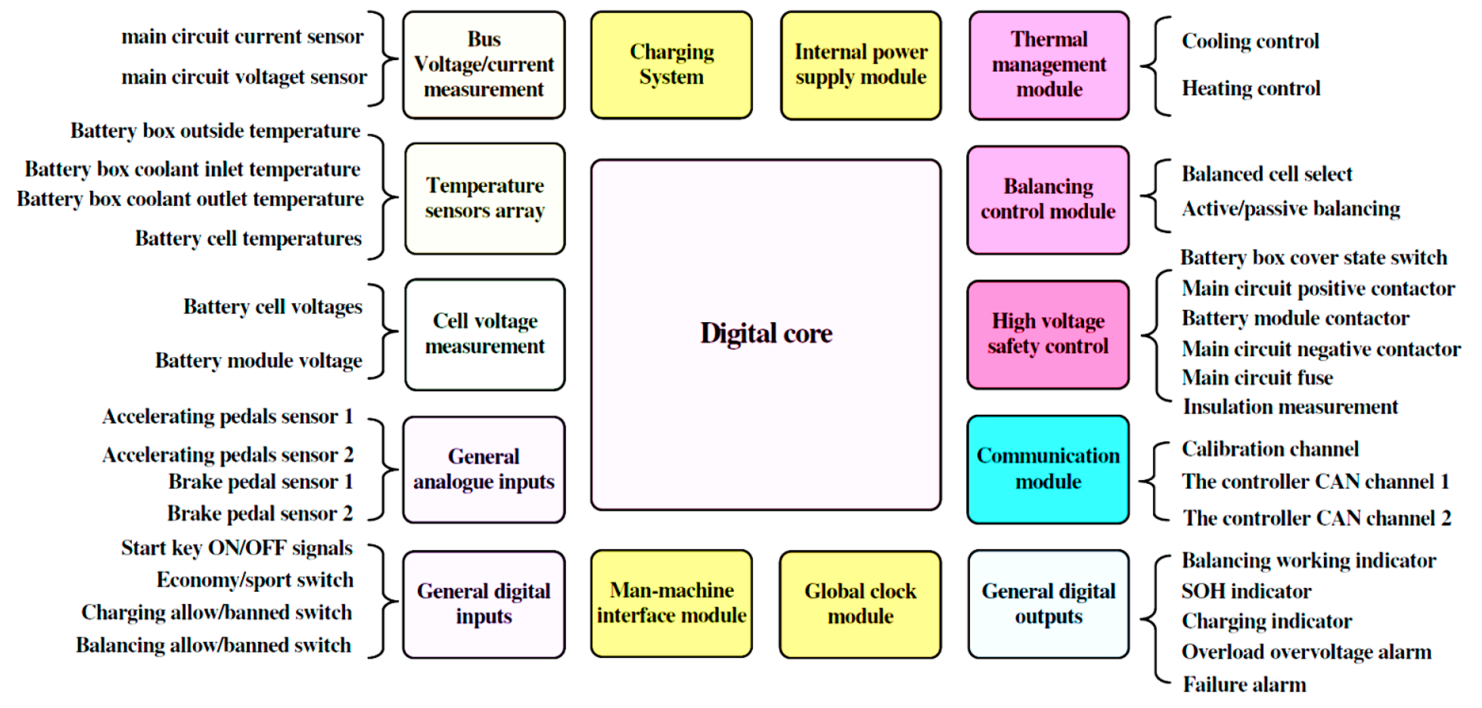

Figure 3. Basic framework of software and hardware of the BMS in vehicles (Reproduced with permission from [39], Copyright Publisher, 2013).

The inputs that the BMS should have are a main circuit current sensor and voltage sensor to measure the main current and voltage; temperature sensors to measure the cell's temperature, the temperature outside the battery box, and maybe also the temperature at the battery coolant inlet and outlet; general analog inputs, like an accelerator pedal sensor and brake pedal sensor; and general inputs, like start key (ON/OFF) signals, charging allow/banned switch, etc. Consequently, the BMS outputs are to the thermal management modules, like fans and electric heaters, to provide cooling and heating control; balancing modules, like capacitors plus switch arrays and dissipation resistance to provide battery equalization; voltage safety management, like a main circuit contactor and battery module contactor; general digital outputs, like a charging indicator and failure alarm; 
and a communication module [39]. The global clock module and the internal power supply module, together with the charging system and man-machine interface module also exist in the BMS.

In Figure 3, the software of the BMS covers various functions, as shown. First the battery parameters are detected, which includes total and individual cell current and voltage, temperature, smoke, insulation, collision, impedance, and so on. This to prevent overcharge or over-discharge. Once all parameters have been detected, the internal battery states $(\mathrm{SOH}, \mathrm{DOD}, \mathrm{SOC}, \mathrm{SOF})$ are estimated and the temperature is controlled according to such conditions as working current, voltage, and temperature. This is done to prevent the battery from operating in hazardous conditions and maintains its performance for a long time [86]. However, the variations of internal parameters can be very high and, thus, affect the battery performance. This can be due to production processes as each cell in a battery pack differs and does not reach the same full charge at the same time during the charge period, and also reaches different SOC during the discharge time. This calls upon the BMS to perform cell balancing.

The BMS also performs an onboard diagnosis to identify any fault that may arise from sensors, actuation, battery, network, overcharge, over-discharge, overload, insulation, extreme temperature rise or fall, loose connections, and so on. After the faults have been diagnosed the EV's system control unit is informed through the network. If a certain threshold value is exceeded, or is likely to be, the BMS can also cut off the power supply to prevent any possible damage from taking place.

The BMS also controls the charger when charging the batteries and adopts reliable battery equalization methods based on the information of each cell that is available. This is done so that each cell's SOC is made as consistent as possible during the charging and discharging period. This ensures that the circuit should deliver a current high enough to perform the required charge redistribution during battery runtime. In order to evaluate the functionality of the overcharge/over-discharge protection system, charging or discharging of the battery is performed beyond the recommended limits by the manufacturer [52].

The heating and cooling process is determined by the BMS based on the overall temperature distribution within the battery pack and the requirements of charge/discharge. However, due to variability in manufacturing, cooling, heating, and other operating conditions, some of the crucial thermal and electrical parameters can vary from cell to cell [87]. Excessively high, low, or uneven temperature will do harm to battery performance, thus, a reasonable battery thermal management system with local thermal control management must be designed, with which it cools down under high temperature conditions, or heats up under low temperature conditions [88]. A safe battery operation is ensured for both surface temperature and internal temperature, which proves to be crucial since the battery's internal temperature can reach a critical condition much quicker than the surface temperature [6]. The EV's LIB system is monitored online, and it is usually real-time. The overall data from the EVs, such as $\mathrm{SOC}, \mathrm{SOH}$, charge/discharge, faults, and so on, is stored by the BMS. In the battery arrangement for EVs, one battery within the pack must be assigned as the master controller, while the rest are assigned as the slaves. In summary, the real-time battery terminal voltage, cell working temperatures, and load current are measured by the BMS, and the online parameters of the battery pack model can be identified by the reduced labeled samples (RLS) based on the real-time data provided by the BMS [89].

\section{Opportunities and Challenges on Prognosis of LIB Health}

Since prognostics are still considered relatively immature (as compared to diagnostics), more focus, so far, has been on developing prognostic methods rather than evaluating and comparing their performances. Consequently, there is a need for dedicated attention towards developing standard methods to evaluate prognostic performance from a viewpoint of how post-prognostic reasoning will be integrated into the health management decision-making process [90]. There are many opportunities for prognostics and health management of LIBs, but they have been met with various challenges in equal measure. In this research we will look at these opportunities and challenges from four 
perspectives, namely, technological, financial/cost, security, and environmental. This paper evaluates each aspect from the opportunities and challenges perspective that LIB research and development is facing. Table 5 shows a summary of opportunities and challenges of LIBs.

Table 5. Summary of opportunities and challenges of LIBs.

\begin{tabular}{|c|c|c|c|}
\hline Aspect & Opportunities & Challenges & References \\
\hline Technological & $\begin{array}{ll}\text { - } & \text { Existence of } \\
\text { recycling technologies } \\
\text { - } & \text { Growth in demand for LIB }\end{array}$ & $\begin{array}{ll}\text { - } & \text { Performance of higher power, larger } \\
\text { energy capacity } \\
\text { - } & \text { RUL Prediction, SOH } \\
\text { - } & \text { diagnosis, Aging } \\
\text { - } & \text { Enduring adverse circumstances } \\
\text { - } & \text { Reliability } \\
\text { - } & \text { Degradation uncertainties }\end{array}$ & {$[1,9,23,60-70]$} \\
\hline Financial/Cost & $\begin{array}{ll}\text { - } & \text { Intelligent cost management } \\
\text { - } & \text { Cost savings }\end{array}$ & $\begin{array}{ll}- & \text { Lower cost } \\
\text { - } & \text { Battery degradation costs } \\
\end{array}$ & {$[14,24,38,61,62,71]$} \\
\hline Security & $\begin{array}{l}\text { Battery state } \\
\text { monitoring system }\end{array}$ & - More safety assurance & {$[48,52,74,88,91]$} \\
\hline Environmental & $\begin{array}{ll}\text { - } & \text { 3R-principle: Recycle, } \\
& \text { reuse, reduce } \\
\text { - } & \text { Mitigated emissions } \\
\text { - } \quad \text { Integration of } \\
\quad \text { renewable energies }\end{array}$ & $\begin{array}{l}\text { - } \quad \text { Disposing waste batteries } \\
\text { - How to reduce production of } \\
\text { new batteries }\end{array}$ & {$[64,68,72-85]$} \\
\hline
\end{tabular}

\subsection{Technological Aspects}

Currently, the vehicle manufacturers use the high-power LIB technology to supply electric and hybrid vehicles [92]. These EVs are supplied with power from a battery pack made up of modules connected in series and/or parallel, depending on the desired voltage supply and storage capacity. Out of this, there are many technological opportunities in the use of LIBs. This includes the existence of recycling technologies, and extensive demand of LIBs. The LIB technology is considered as one of the most promising for the near future by a majority of literary sources [11]. However, a great deal has to be done to ensure that batteries of higher power performance and larger energy capacity are realized, as well as improving the batteries to endure adverse circumstances. Consequently, the prediction of RUL, monitoring of battery aging, and $\mathrm{SOH}$ diagnosis requires technologies that are accurate in order to avoid catastrophic failures. LIBs provide a lower range of kilometers for EVs as compared to gasoline vehicles, thus, technologies require improvements towards ensuring that higher power energy density is achieved [93].

LIB technologies are very promising for the development of future-generation EVs. These sets of batteries exhibit several advantages as demonstrated, together with various appealing features making them a darling use in many applications. This is explained by the way it has caught the market share in commercialization in consumer electronics, such as cell phones, laptops, video cameras, digital cameras, power tools, and other portable electronic devices [46]. LIBs have many advantages which include $[1,34,46,91,94,95]$ :

- Light weight: applications that make use of LIB go farther and faster due to their lightweight.

- High energy density: EV operates longer between charges while still consuming the same amount of power. LIBs are highly efficient and can be charged with electricity or renewable energies [11].

- Low self-density: the rate of self-discharge is far lower than that of lead acid batteries [96].

- No maintenance: LIBs require little to no maintenance to maintain high-performing products.

- Faster recharge: LIBs have little to no resistance, which allows you to charge at a much higher rate.

- Customizable: not only are LIBs more powerful, lighter, and hold charge longer than lead acid batteries, but they are customizable to fit your needs. 
The distance travelled by EVs after full charging is determined by the size of the battery pack (Wh) against the energy consumption $(\mathrm{Wh} / \mathrm{km})$ :

$$
\text { Distance travelled }(\mathrm{km})=\frac{\text { Battery pack size }(\mathrm{Wh})}{\text { Energy consumption }(\mathrm{Wh} / \mathrm{km})}
$$

According to the study conducted by Martinez et al. it is revealed through the literature that the total distance an EV can cover after a full recharge process is $200 \mathrm{~km}$ due to their weight and number of batteries [97]. This signifies that more research is required on how the power efficiency can be increased to offer higher distances travelled by EVs.

\subsection{Cost Aspects}

The cost and performance of the LIBs are the most expensive component in a vehicle, and is directly linked with the adoption of EVs [18,98], however, in the recent past this cost have been reduced significantly by almost 65\% from 2010 [65]. Several countries are working around the clock to see how best they can substitute fossil-based powered energies for technological options of greener/renewable energy to further cut the cost, as well as to conserve the environment. Manufacturers are working on how to employ intelligent cost management methods in order to produce low-cost LIBs. This is partly achieved by recycling used LIBs, which could have gone into waste dumped in a landfill. However, the development of LIBs, and its certification of safety-critical applications, are very expensive.

These costs can be reduced by encapsulating safety-critical components, and safety measures can be restricted to the respective parts [35]. Accounting for battery aging is crucial as the cost of LIBs has a crucial significant impact on overall system cost. The modeled battery degradation cost includes the impacts of the battery temperature, the average SOC, and the DOD on the fading LIB capacity [99]. However, the general cost of batteries reduced tremendously from $1000 \$ / \mathrm{kWh}$ in 2008, to $268 \$ / \mathrm{kWh}$ in 2015 , which is a $73 \%$ reduction in seven years [100]. If this trend continues, it looks promising to consumers of EVs in the future, but if alternative measures to sources of energy are not sought, then the meager resources for the manufacture of LIBs will be depleted.

\subsection{Security Aspects}

Safety of LIBs is paramount to ensure confidence and widespread adoption of electro-mobility in our society, as they are a proven technology for automotive applications and their continuous use in the future is undeniable. For enhanced security and more accurate SOC estimation, the parameter values of the equivalent circuit models (ECMs) should be continually updated since surface temperature measurements alone might not be sufficient to ensure safe battery operation [58]. During cycling, cells within a pack exhibit non-uniform properties, which may lead to some imbalances (e.g., voltage variations between cells) that may trigger a safety hazard [52]. When EVs are used outdoors, poor pavement conditions, changes in temperature and load can cause performance degradation in LIBs. Battery degradation may lead to leakage, insulation damage, and partial short-circuit. If there is no online detection of degradation, further battery usage will cause serious situations, such as spontaneous combustion and explosions, especially if the current state of health has not been assessed in a timely fashion, or the future battery health state has not been estimated [74]. The main thermal safety issues of LIBs to be addressed are overheating, combustion, explosion, and cycle life. To avoid any catastrophic incidences caused by degradation of LIBs, and to predictively maintain the safety of vehicles, carrying out research on RUL prognostics of LIBs is of great importance [48,52,74,88].

\subsection{Environmental Aspects}

The use of LIBs will be the next big thing as many governments are fighting against production and sale of vehicles powered only by fossil fuels in favor of cleaner vehicles. This is in a bid to clean up the country's air, or in fighting against global warming, thus ensuring zero-emission vehicles (ZEV). 
EVs are seen as an alternative to the conventional transportation based on combustion engines, looking to contribute to solving environmental issues related with zero emissions policies. For this case the EVs are projected as the most sustainable solutions for future transportation [101]. EVs have many advantages over conventional hydrocarbon internal combustion engines, including energy efficiency, environmental friendliness, noiselessness, and less dependence on fossil fuels [102].

According to the International Energy Agency (IEA) report, there is an alarming statistic that shows just how far many other countries have to go in expunging the use of fossil-powered vehicles from their roads. Globally, $95 \%$ of EVs are sold in only 10 countries: China, the U.S., Japan, Canada, Norway, the U.K., France, Germany, the Netherlands, and Sweden [103]. This global statistic still poses a challenge to researchers and environmental enthusiasts in regard to the uptake of zero-emission vehicles or green vehicles globally. There are several opportunities in relation to environmental aspects in the use, production, and sale of green vehicles, or at least hybrid ones, which is a boost to the fight against global warming and puts pressure on the extensive use, production, and sale of EVs. Several environmental opportunities that exist include, but are not limited to, the 3R principle: recycle, reuse, reduce, mitigated emissions, and integration of renewable energies.

\subsubsection{R Principle: Recycle, Reuse, and Reduce}

The sharp growing volume of spent LIBs $[63,104,105]$, requires a well-functioning collection and recycling infrastructure to minimize associated environmental impacts and maximize the batteries' reuse potential [62]. The recycling of LIBs reduces energy consumption, reduces greenhouse gas emissions, and results in considerable natural resource savings when compared to landfill [106]. However, it is unclear which recycling processes have the least impact on the environment. There is need for incentives from government and non-governmental agencies to LIB recyclers as a motivating factor to improve recycling, thus mitigating the pressure on the scarce raw material. If the raw materials come from ores, significant negative environmental factors can occur from ore mining and processing, and these can be avoided if the material can be recycled.

Spent $\mathrm{LiFePO}_{4}$ battery packs will retain approximately $80 \%$ of their performance, allowing the pack to be applied in a second application, such as a stationary energy storage system [98]. In these spent $\mathrm{LiFePO}_{4}$ batteries, whenever they are recycled at the end of their useful life, a great deal of valuable metals can be recovered, such as copper, aluminum, magnesium, nickel, cobalt, and lithium, thus reducing the pressure on mining the ore, environmental contamination problems [107], and the costs of production. Consequently the LIB consumers require awareness on taking part on the 3R-principle. Since many consumers prefer new batteries, resulting in spent batteries having little potential for reuse, end up being dumped along with other urban solid waste.

Taking into account the importance of key parameters for the environmental performance of LIBs, research efforts should not only focus on energy density, but also on maximizing cycle life and charge/discharge efficiency [42]. The application of the 3R principle to LIBs will bring savings quantified in terms of energy and cumulative energy extracted from the natural environment [108]. It will be seen how material or cell recovery from existing cells will be another source of future materials for LIBs [83]. Therefore, the $3 \mathrm{R}$ rule for reuse, recycle, and reduce should be employed purposely to reduce the extinction of the rare iron ores, and this will go along with the conservation of the environment. Current research is aimed towards these principles to improve on the technologies around it.

\subsubsection{Mitigated Emissions}

The benefits of mitigated emissions include reduced air pollution and climate change, and increased integration and penetration of renewable sources of energy [109]. There are many government policies which are being set out to mitigate emissions from vehicles, as shown in Table 5 . One of the policies is the encouragement of EVs, green energy-powered vehicles, and/or hybrid 
vehicle production, sale, and usage. Some states worldwide have set timelines and others are planning on the shift to EVs. Table 6 shows a summary of the progress so far.

Table 6. Countries that want to ban gas and diesel.

\begin{tabular}{|c|c|c|}
\hline Country & Year & Expectations \\
\hline Norway & 2025 & $\begin{array}{l}\text { - All new passenger cars and vans sold by } 2025 \text { should be zero emission vehicles. } \\
\text { As per } 2016,40 \% \text { of cars sold were electric and hybrid. it is leading the way }\end{array}$ \\
\hline India & 2030 & - $\quad$ Projection of having every vehicle sold to be powered by electricity \\
\hline France & $\begin{array}{c}2040 \\
\text { After-2040 }\end{array}$ & $\begin{array}{l}\text { - To end the sale of gas and diesel powered vehicles as it fights global warming } \\
\text { - Automakers will only be allowed to sell cars that run on electricity/other cleaner } \\
\text { power. Hybrid cars will also be permitted }\end{array}$ \\
\hline Britain & $\begin{array}{l}2040 \\
2050\end{array}$ & $\begin{array}{l}\text { - To ban sales of new gasoline and diesel cars in a bid to clean up the country's air. } \\
\text { - All cars on the road will need to be have zero emissions }\end{array}$ \\
\hline China & - & $\begin{array}{l}\text { - Working on a plan to ban production and sale of vehicles powered only by } \\
\text { fossil fuels. }\end{array}$ \\
\hline
\end{tabular}

Other countries in the league are Austria, Denmark, Ireland, Netherlands, Japan, Portugal, Korea, and Spain, who have set official targets for EV sales. The USA does not have a federal policy, but at least eight states have set out goals. According to the IEA, India will join China and the USA to account for $2 / 3$ of the world's expansion in renewable power sources from solar and wind [110]. This is a clear indicator that the demand for LIBs will soar high when new players join the league, as well as the current ones up their game.

\subsubsection{Integration of Renewable Energies}

The demand for electricity storage capability for EVs is on the rise, and it will increase even more in the future. To support EVs' electric storage there have recently been increases in the contribution of renewable energies to the electrical supply mainly from the installation of photovoltaic modules and wind turbines [111]. Therefore, the internal combustion engine can be replaced with small-sized photovoltaic (PV) modules located on the roof of the EVs, and a micro-wind turbine located in front of the EVS, behind the condenser of the air conditioning system [112]. This technique will improve the power efficiency, regulate the DC-link accurately, and produce suitable stator currents for the traction motor. This is followed by the fact that, by 2030, the demand for energy consumption for EVs will increase to 50\% and 40\% in USA and Europe, and double for India and China, respectively. Therefore, renewable energy remains the only important resource to consider [59].

\section{Future Research Agenda}

Currently, there is a scarcity of real prognostics to meet industrial challenges. This may be due to inherent uncertainties associated with deterioration processes, lack of sufficient quantities of data, sensor noise, unknown environmental and operating conditions, and engineering variations, etc., which prevents building prognostic models that can accurately capture the evolution of degradation [14]. This makes research in battery health management a worthy area of future research. This is attributed to the over-emphasis on electrification of our vehicles on our roads today in many countries so as to reduce emissions, and the environmental impact on the depletion of fossil fuels [113]. However, this vehicle electrification has to be regulated to ensure that desirable benefits are achieved in the long run. The solution is, perhaps, the investment on EV powered by alternative solutions.

Cost Effective Production: this is mainly an industrial topic, but a very important future research direction to reduce the price of EVs on the market and thereby widen the customer base [113]. Investment on better technologies which can cause less degradation, but lead to higher energy efficiency on a large scale, and lower long-term costs, is required to be researched. The cost and performance of the battery, the most expensive component in a vehicle, is directly linked with the adaption of 
electric vehicles. The adoption towards battery electric vehicles mainly depends on the willingness to pay for the extra cost of the traction battery [93]. However the cost can significantly be reduced by economies of scale, and implementing an accurate SOC estimation strategy [114]. The technological breakthroughs in battery life, abuse tolerance and drive range will eventually result in the development of cost effective, long-lasting LIBs.

Disposal of replaced battery: Since spent LiBs retain some of their electrical power, their improper disposal can cause explosions, posing massive environmental, human health or safety hazards and necessitating expensive clean-up and mitigation measures [62]. A lot has to be done to see how this challenge is over done in future. How will the replaced batteries be disposed without posing an environmental impact is another research area in future? Research has to be conducted on how to further extract their useful energy capacity to make an extra profit, while saving out the rare battery resource. Also since pent batteries are defined as hazardous waste, further improvements on basic requirements for packaging, collection, storage, transport, and disposal should be addressed adequately, mainly from scientific research [115] and industrial practices.

Life cycle assessment: research on the LIBs used in EVs must be conducted so that the life cycle study on system boundary [115] can be assessed. Materials used in LIBs production that are rare, toxic, and difficult to recycle should be avoided for improvement of the environment. According to [43], if the model simulations show that cell change-out extends pack life indefinitely while maintaining pack performance at a steady-state, the concept would be of interest to EV and battery manufacturers for its economic benefits, and will hopefully lead to a reduced load of batteries on the recycling and disposal infrastructure.

Identifiability: identifiability in battery $\mathrm{SOH}$ estimation is required to establish how to estimate the progress of different battery aging effects. This is perhaps one of the largest challenges in battery $\mathrm{SOH}$ estimation [116]. Specifically, the fact that different battery aging dynamics are complex, intertwined, and similar in their time constants means that it is fundamentally very difficult to estimate the progress of different battery aging effects online using voltage, current, and temperature measurements. This, in turn, makes it very challenging to estimate the health of LIBs online, predict their death, and control them in a manner that postpones such death. Battery identifiability remains a very open research area whose exploration can shed light on the extremely important question of what additional sensors, beyond terminal current, temperature, and voltage, can provide with respect to the best means for onboard battery health prognostics, diagnostics, and control [117], using various model estimation algorithms. There are a number of $\mathrm{SOH}$ estimation algorithms in battery management systems, but one of the important classes of estimation algorithms is the equivalent circuit model [51].

Developing second-use technology of retired EVs' LIBs: the already retired EVs' LIBs require some research to establish how they can be best put into meaningful second use. According to Wang et al. [94] recycling of spent $\mathrm{LiFePO}_{4}$ batteries is important not only for the treatment of waste, but also for the recovery of useful resources. However they further observed that the treatment of spent $\mathrm{LiFePO}_{4}$ batteries is challenging because $\mathrm{LiFePO}_{4}$ batteries do not contain any precious metals, treatment is complex using traditional recycling processes, and the number of spent batteries recovered from the public has been very small recently, and is faced with challenges. The major challenge that must to be addressed by the recycling industry is developing economical ways to extract and process these metals [118]. Furthermore, there is still a lack of adequate policy and feasible technology for addressing retired LIBs [104], thus, there needs to be recycling processes developed that have economic advantages in terms of chemical costs and added value [34].

Lowering capacity degradation: the LIB capacity is influenced by many factors; among them are temperature, vibrations, and other unforeseen environmental factors. Thus, the efficiency of energy required keeps varying over time [119]. This energy efficiency in LIBs reflects charging and discharging energy powers of the same cycle, and so it is closely related to the battery capacity. Energy efficiency is 
defined as the percentage of energy use which actually achieves the energy service required [16]. It is given by:

$$
\eta=\frac{W_{D}}{W_{C}} \times 100 \%
$$

where $W_{D}$ is the energy efficiency during discharge, and $W_{C}$ is the energy efficiency during charging. Due to high energy density per weight, LIBs are a better option than lead acid batteries in EV application $[34,36,120,121]$. However, much degradation cannot be prevented, and the real lifetime of the LIBs can be extended by using various other types of approaches.

\section{Summary and Closing Remarks}

EVs are considered one of the novel solutions to the transport system since they reduce over-dependence on fossil energy. This, in return, will reduce carbon emissions, as EVs act as greener solutions in the transport industry. However, research has shown that the major challenge of the LIBs is battery life. This, however, can be extended by cell balancing to ensure safety of the systems, as well as reliability. The manner in which BMS offers this safety is two-fold: safety of persons and safety of cells. The current growth of EVs is anticipated to lead to enormous penetration into the electric power grid, thus calling for innovative ways of supplementing the EV's power. This is feared because the over-dependence on electric power may add to extensive loads on the power grid, which will have extensive effects on existing distribution networks.

This paper presented a comprehensive review in terms of battery health management for EVs. First the health management systems for batteries are introduced by battery terminologies, BMS architecture, stages of performing BMS, and the prognostic methods used in performing battery health. Furthermore, the opportunities and challenges of BMS from three perspectives, namely technological, cost, security, and environmental aspects was reviewed. Finally, the future research agendas are discussed. In the future the production of cost-effective LIBs, the disposal of replaced LIBs, life-cycle assessment, development of second-use technologies of retired EV batteries, and how battery degradation can be reduced should be the focus of research. Therefore, in regard to the issues raised for research in this paper, further exploration is essential.

Author Contributions: All authors contributed to the paper. Z.B.O. wrote the manuscript with the supervision from L.Z. and D.S., L.Z. acted as a corresponding author.

Funding: This work was financially supported by the China Scholarship Council (CSC). This work was also financially supported by the National Key Research and Development Program of China (No. 2016YFF0203804) and the National Natural Science Foundation of China (No. 51775037).

Conflicts of Interest: The authors declare no conflict of interest. The funding sponsors had no role in the design of the study; in the collection, analyses, or interpretation of data; in the writing of the manuscript; or in the decision to publish the results.

\section{References}

1. Raszmann, E.; Baker, K.; Shi, Y.; Christensen, D. Modeling stationary lithium-ion batteries for optimization and predictive control. In Proceedings of the 2017 IEEE Power and Energy Conference at Illinois (PECI), Champaign, IL, USA, 23-24 February 2017. [CrossRef]

2. Liu-Henke, X.; Scherler, S.; Jacobitz, S. Verification oriented development of a scalable battery management system for lithium-ion batteries. In Proceedings of the 2017 Twelfth International Conference on Ecological Vehicles and Renewable Energies (EVER), Monte Carlo, Monaco, 11-13 April 2017. [CrossRef]

3. Ordoñez, J.; Gago, E.J.; Girard, A. Processes and technologies for the recycling and recovery of spent lithium-ion batteries. Renew. Sustain. Energy Rev. 2016, 60, 195-205. [CrossRef]

4. Dubarry, M.; Devie, A.; Liaw, B.Y. The value of battery diagnostics and prognostics. J. Energy Power Sources 2014, 1, 242-249.

5. Song, Y.; Liu, D.; Yang, C.; Peng, Y. Data-driven hybrid remaining useful life estimation approach for spacecraft lithium-ion battery. Microelectron. Reliab. 2017, 75, 142-153. [CrossRef] 
6. Muñoz-Galeano, R.-B.N.; Pablo, J.; Sarmiento-Maldonado, H.O. SoC estimation for lithium-ion batteries: review and future challenges. Electronics 2017, 6, 102. [CrossRef]

7. Zhang, L.; Mu, Z.; Sun, C. Remaining useful life prediction for lithium-ion batteries based on exponential model and particle filter. IEEE Access 2018, 6, 17729-17740. [CrossRef]

8. Daowd, M.; Antoine, M.; Omar, N.; Lataire, P.; van den Bossche, P.; van Mierlo, J. Battery management system-balancing modularization based on a single switched capacitor and bi-directional DC/DC converter with the auxiliary battery. Energies 2014, 7, 2897-2937. [CrossRef]

9. Fujita, Y.; Hirose, Y.; Kato, Y.; Watanabe, T. Development of battery management system. FUJITSU TEN Tech. J. 2016, 42, 68-80.

10. Allam, A.; Onori, S.; Marelli, S.; Taborelli, C. Battery health management system for automotive applications: A retroactivity-based aging propagation study. In Proceedings of the American Control Conference (ACC), Chicago, IL, USA, 1-3 July 2015; pp. 703-716. [CrossRef]

11. Andwari, A.M.; Pesiridis, A.; Rajoo, S.; Martinez-Botas, R.; Esfahanian, V. A review of battery electric vehicle technology and readiness levels. Renew. Sustain. Energy Rev. 2017, 78, 414-430. [CrossRef]

12. Akdere, M.; Giegerich, M.; Wenger, M.; Schwarz, R.; Koffel, S.; Fühner, T.; Waldhör, S.; Wachtler, J.; Lorentz, V.R.H.; März, M. Hardware and software framework for an open battery management system in safety-critical applications. In Proceedings of the IECON 2016-42nd Annual Conference of the IEEE Industrial Electronics Society, Florence, Italy, 23-26 October 2016; pp. 5507-5512. [CrossRef]

13. Brandl, M.; Gall, H.; Wenger, M.; Lorentz, V.; Giegerich, M.; Baronti, F.; Fantechi, G.; Fanucci, L.; Roncella, R.; Saletti, R.; et al. Batteries and battery management systems for electric vehicles. In Proceedings of the 2012 Design, Automation \& Test in Europe Conference \& Exhibition (DATE), Dresden, Germany, 12-16 March 2012; pp. 971-976. [CrossRef]

14. Javed, K.; Gouriveau, R.; Zerhouni, N. State of the art and taxonomy of prognostics approaches, trends of prognostics applications and open issues towards maturity at different technology readiness levels. Mech. Syst. Signal Process. 2017, 94, 214-236. [CrossRef]

15. Xing, Y.; Ma, E.W.M.; Tsui, K.L.; Pecht, M. Battery management systems in electric and hybrid vehicles. Energies 2011, 4, 1840-1857. [CrossRef]

16. Wang, S.; Zhao, L.; Su, X.; Ma, P. Prognostics of lithium-ion batteries based on battery performance analysis and flexible support vector regression. Energies 2014, 7, 6492-6508. [CrossRef]

17. Bruen, T.; Hooper, J.M.; Marco, J.; Gama, M.; Chouchelamane, G.H. Analysis of a battery management system (BMS) control strategy for vibration aged Nickel Manganese Cobalt Oxide (NMC) Lithium-Ion 18650 battery cells. Energies 2016, 9, 255. [CrossRef]

18. Shareef, H.; Islam, M.M.; Mohamed, A. A review of the stage-of-the-art charging technologies, placement methodologies, and impacts of electric vehicles. Renew. Sustain. Energy Rev. 2016, 64, 403-420. [CrossRef]

19. Castro, T.S.; de Souza, T.M.; Silveira, J.L. Feasibility of electric vehicle: electricity by grid $\times$ photovoltaic energy. Renew. Sustain. Energy Rev. 2017, 69, 1077-1084. [CrossRef]

20. Coffman, M.; Bernstein, P.; Wee, S. Integrating electric vehicles and residential solar PV. Transp. Policy 2017, 53, 30-38. [CrossRef]

21. Gough, R.; Dickerson, C.; Rowley, P.; Walsh, C. Vehicle-to-grid feasibility: A techno-economic analysis of EV-based energy storage. Appl. Energy 2017, 192, 12-23. [CrossRef]

22. Hannan, M.A.; Azidin, F.A.; Mohamed, A. Hybrid electric vehicles and their challenges: A review. Renew. Sustain. Energy Rev. 2014, 29, 135-150. [CrossRef]

23. Palinski, M. A Comparison of electric vehicles and conventional automobiles: Costs and quality perspective. Bachelor's Thesis, Novia University of Applied Sciences, Vaasa, Finland, 2017.

24. Salisbury, M. Economic and Air Quality Benefits of Electric Vehicles in Nevada Executive Summary. Southwestern Energy Efficiency Project (SWEEP). 2014. Available online: http:/ /www.swenergy.org/data/ sites/1/media/documents/publications/documents/Economic_and_AQ_Benefits_of_EVs_in_NV-Sept_ 2014.pdf (accessed on 10 April 2018).

25. Helmers, E.; Patrick, M. Electric cars: Technical characteristics and environmental impacts. Environ. Sci. Eur. 2012, 24, 14. [CrossRef]

26. Pappas, J.C.K. A New Prescription for electric cars. Energy Law J. 2014, 35, 151-198.

27. Hall, D.; Moultak, M.; Lutsey, N. Electric Vehicle Capitals of the World: Demonstrating the Path to Electric Drive; International Council on Clean Transportatio: Washington, DC, USA, 2017. 
28. Varun, M.; Kumar, C. Problems in electric vehicles. Int. J. Appl. Res. Mech. Eng. 2012, 2, 63-73.

29. Saha, B.; Quach, C.C.; Hogge, E.F.; Strom, T.H.; Hill, B.L.; Goebel, K. Battery health management system for electric UAVs. In Proceedings of the 2011 Aerospace Conference, Big Sky, MT, USA, 5-12 March 2011. [CrossRef]

30. Cazzola, P.; Gorner, M.; Munuera, L. Global EV Outlook 2017: Two Million and Counting. International Energy Agency (IEA). 2017. Available online: https:/ / webstore.iea.org/global-ev-outlook-2017 (accessed on 22 February 2018).

31. Zhang, L.; Peng, H.; Ning, Z.; Mu, Z.; Sun, C. Comparative research on RC equivalent circuit models for lithium-ion batteries of electric vehicles. Appl. Sci. 2017, 7, 1002. [CrossRef]

32. Rezvani, M.; Abuali, M.; Lee, S.; Lee, J.; Ni, J. A comparative analysis of techniques for electric vehicle battery Prognostics and Health Management (PHM). SAE Int. 2011, 11. [CrossRef]

33. Xi, Z.; Jing, R.; Yang, X.; Decker, E. State of charge estimation of lithium-ion batteries considering model Bias and parameter uncertainties. In Proceedings of the ASME 2014 International Design Engineering Technical Conferences \& Computers and Information in Engineering Conference, Buffalo, NY, USA, 17-20 August 2014; pp. 1-7. [CrossRef]

34. Li, L.; Bian, Y.; Zhang, X.; Xue, Q.; Fan, E.; Wu, F.; Renjie Chen, R. Economical recycling process for spent lithium-ion batteries and macro- and micro-scale mechanistic study. J. Power Sources 2018, 377, 70-79. [CrossRef]

35. Li, J.; Lai, Q.; Wang, L.; Lyu, C.; Wang, H. A method for SOC estimation based on simplified mechanistic model for $\mathrm{LiFePO}_{4}$ battery. Energy 2016, 114, 1266-1276. [CrossRef]

36. Podder, S.; Khan, M.Z.R. Comparison of lead acid and Li-ion battery in solar home system of Bangladesh. In Proceedings of the 2016 5th International Conference on Informatics, Electronics and Vision, ICIEV, Dhaka, Bangladesh, 13-14 May 2016; pp. 434-438. [CrossRef]

37. Leone, G.; Cristaldi, L.; Turrin, S. A data-driven prognostic approach based on statistical similarity: An application to industrial circuit breakers. Measurement 2017, 108, 163-170. [CrossRef]

38. Wei, J.; Dong, G.; Chen, Z. Remaining useful life prediction and state of health diagnosis for lithium-ion batteries using particle filter and support vector regression. IEEE Trans. Ind. Electron. 2017, 65, 5634-5643. [CrossRef]

39. Lu, L.; Han, X.; Li, J.; Hua, J.; Ouyang, M. A review on the key issues for lithium-ion battery management in electric vehicles. J. Power Sources 2013, 226, 272-288. [CrossRef]

40. Saxena, A.; Celaya, J.R. Roychoudh loading profiles: Some lessons learned. In Proceedings of the European Conference on Prognostics and Health Management Society, Dresden, Germany, 3-5 July 2012.

41. Chen, A.; Sen, P.K. Advancement in battery technology: a state-of-the-art review. In Proceedings of the 2016 IEEE Industry Applications Society Annual Meeting, Portland, OR, USA, 2-6 October 2016. [CrossRef]

42. Peters, J.F.; Baumann, M.; Zimmermann, B.; Braun, J.; Weil, M. The environmental impact of Li-Ion batteries and the role of key parameters-A review. Renew. Sustain. Energy Rev. 2017, 67, 491-506. [CrossRef]

43. Mathew, M.; Kong, Q.H.; McGrory, J.; Fowler, M. Simulation of lithium ion battery replacement in a battery pack for application in electric vehicles. J. Power Sources 2017, 349, 94-104. [CrossRef]

44. Su, X.; Wang, S.; Pecht, M.; Zhao, L.; Ye, Z. Interacting multiple model particle filter for prognostics of lithium-ion batteries. Microelectron. Reliab. 2017, 70, 59-69. [CrossRef]

45. Khorasgani, H.; Biswas, G.; Sankararaman, S. Methodologies for system-level remaining useful life prediction. Reliab. Eng. Syst. Saf. 2016, 154, 8-18. [CrossRef]

46. Chen, X.; Shen, W.; Vo, T.T.; Cao, Z.; Kapoor, A. An overview of lithium-ion batteries for electric vehicles. In Proceedings of the 2012 10th International Power \& Energy Conference, Ho Chi Minh City, Vietnam, 12-14 December 2012; pp. 230-235. [CrossRef]

47. Piromjit, P.; Tayjasanant, T. Peak-demand management for improving undervoltages in distribution systems with electric vehicle connection by stationary battery. In Proceedings of the 2017 IEEE Transportation Electrification Conference and Expo, Asia-Pacific (ITEC Asia-Pacific), Harbin, China, 7-10 August 2017. [CrossRef]

48. Zhang, F.; Rehman, M.M.U.; Zane, R.; Maksimovic, D. Hybrid balancing in a modular battery management system for electric-drive vehicles. In Proceedings of the 2017 IEEE Energy Conversion Congress and Exposition (ECCE), Cincinnati, OH, USA, 1-5 October 2017; pp. 578-583. [CrossRef] 
49. Fleischer, C.; Sauer, D.U.; Barreras, J.V.; Schaltz, E.; Christensen, A.E. Development of software and strategies for battery management system testing on HIL simulator. In Proceedings of the 2016 Eleventh International Conference on Ecological Vehicles and Renewable Energies (EVER), Monte Carlo, Monaco, 6-8 April 2016. [CrossRef]

50. Rahimi-Eichi, H.; Ojha, U.; Baronti, F.; Chow, M.-Y. Battery management system: An overview of its application in the smart grid and electric vehicles. IEEE Ind. Electron. Mag. 2013, 4-16. [CrossRef]

51. Zhang, L.; Ning, Z.; Peng, H.; Mu, Z.; Sun, C. Effects of vibration on the electrical performance of lithium-ion cells based on mathematical statistics. Appl. Sci. 2017, 7, 802. [CrossRef]

52. Ruiz, V.; Pfrang, A.; Kriston, A.; Omar, N.; van den Bossche, P.; Boon-Brett, L. A review of international abuse testing standards and regulations for lithium ion batteries in electric and hybrid electric vehicles. Renew. Sustain. Energy Rev. 2018, 81, 1427-1452. [CrossRef]

53. Artakusuma, D.D.; Afrisal, H.; Cahyadi, A.I.; Wahyunggoro, O. Battery management system via bus network for multi battery electric vehicle. In Proceedings of the 2014 IEEE International Conference on Electrical Engineering and Computer Science, Kuta, Indonesia, 24-25 November 2014; pp. 179-181. [CrossRef]

54. Sonoc, A.; Jeswiet, J.; Soo, V.K. Opportunities to improve recycling of automotive lithium ion batteries. Procedia CIRP 2015, 29, 752-757. [CrossRef]

55. Nuhic, A.; Terzimehic, T.; Soczka-guth, T.; Buchholz, M.; Dietmayer, K. Health diagnosis and remaining useful life prognostics of lithium-ion batteries using data-driven methods. J. Power Sources 2013, 239, 680-688. [CrossRef]

56. Belkacem, L.; Simeu-abazi, Z.; Dhouibi, H.; Gascard, E.; Messaoud, H. Diagnostic and prognostic of hybrid dynamic systems: Modeling and RUL evaluation for two maintenance policies. Reliab. Eng. Syst. Saf. 2017, 164, 98-109. [CrossRef]

57. Pastor-Fernández, C.; Widanage, W.D.; Chouchelamane, G.H.; Marco, J. A SoH diagnosis and prognosis method to identify and quantify degradation modes in li-ion batteries using the IC/DV technique. In Proceedings of the 6th Hybrid and Electric Vehicles Conference (HEVC 2016), London, UK, 2-3 November 2016. [CrossRef]

58. Hannan, M.A.; Lipu, M.S.H.; Hussain, A.; Mohamed, A. A review of lithium-ion battery state of charge estimation and management system in electric vehicle applications: Challenges and recommendations. Renew. Sustain. Energy Rev. 2017, 78, 834-854. [CrossRef]

59. Melhem, F.Y.; Grunder, O.; Hammoudan, Z.; Moubayed, N. Optimization and energy management in smart battery storage system with integration of electric vehicles. Can. J. Electr. Comput. Eng. 2017, 40, 128-138. [CrossRef]

60. Giegerich, M.; Akdere, M.; Freund, C.; Fuhner, T.; Grosch, J.L.; Koffel, S.; Schwarz, R.; Waldhor, S.; Wenger, M.; Lorentz, V.R.H.; et al. Open, flexible and extensible battery management system for lithium-ion batteries in mobile and stationary applications. In Proceedings of the 2016 IEEE 25th International Symposium on Industrial Electronics (ISIE), Santa Clara, CA, USA, 8-10 June 2016; pp. 991-996. [CrossRef]

61. Gaines, L. The future of automotive lithium-ion battery recycling: Charting a sustainable course. Sustain. Mater. Technol. 2014, 1-2, 2-7. [CrossRef]

62. Zeng, X.; Li, J.; Liu, L. Solving spent lithium-ion battery problems in China: Opportunities and challenges. Renew. Sustain. Energy Rev. 2015, 52, 1759-1767. [CrossRef]

63. Wei, J.; Zhao, S.; Ji, L.; Zhou, T.; Miao, Y.; Scott, K.; Li, D.; Yang, J.; Wu, X. Reuse of Ni-Co-Mn oxides from spent Li-ion batteries to prepare bifunctional air electrodes. Resour. Conserv. Recycl. 2018, 129, 135-142. [CrossRef]

64. Yusof, M.S.; Toha, S.F.; Kamisan, N.; Hashim, N.N.W.N.; Abdullah, M. Battery cell balancing pptimisation for battery management system. IOP Conf. Ser. Mater. Sci. Eng. 2017, 184, 012021. [CrossRef]

65. Rahman, A.; Rahman, M.; Rashid, M. Wireless battery management system of electric transport. IOP Conf. Ser. Mater. Sci. Eng. 2017, 260, 012029. [CrossRef]

66. Piao, C.; Wang, Z.; Cao, J.; Zhang, W.; Lu, S. Lithium-ion battery cell-balancing algorithm for battery management system based on real-time outlier detection. Math. Probl. Eng. 2015, 2015. [CrossRef]

67. Lin, J.-C.M. Development of a new battery management system with an independent balance module for electrical motorcycles. Energies 2017, 10, 1289. [CrossRef] 
68. Liang, Y.; Wang, Y.; Han, D. Design of energy storage management system based on FPGA in design of energy storage management system based on FPGA in Micro-Grid. IOP Conf. Ser. Earth Environ. Sci. 2017, 108, 052040. [CrossRef]

69. Sutharssan, T.; Montalvao, D.; Chen, Y.K.; Wang, W.-C.; Pisac, C.; Elemara, H. A review on prognostics and health monitoring of proton exchange membrane fuel cell. Renew. Sustain. Energy Rev. 2017, 75, 440-450. [CrossRef]

70. Elattar, H.M.; Elminir, H.K.; Riad, A.M. Prognostics: A literature review. Complex Intell. Syst. 2016, 2, $125-154$. [CrossRef]

71. Goebel, K.; Saha, B.; Saxena, A.; Celaya, J.R.; Christophersen, J.P. Prognostics in battery health management. IEEE Instrum. Meas. Mag. 2008, 11, 33-40. [CrossRef]

72. Tsui, K.L.; Chen, N.; Zhou, Q.; Hai, Y.; Wang, W. Prognostics and health management: A review on data driven approaches. Math. Probl. Eng. 2014, 2015. [CrossRef]

73. Wang, D.; Yang, F.; Zhao, Y.; Tsui, K.L. Battery remaining useful life prediction at different discharge rates. Microelectron. Reliab. 2017, 78, 212-219. [CrossRef]

74. Wu, L.; Fu, X.; Guan, Y. Review of the remaining useful life prognostics of vehicle lithium-ion batteries using data-driven methodologies. Appl. Sci. 2016, 6, 166. [CrossRef]

75. Zhou, D.; Xue, L.; Song, Y.; Chen, J. On-Line Remaining useful life prediction of lithium-ion batteries based on the optimized Gray Model GM(1,1). Batteries 2017, 3, 21. [CrossRef]

76. Arachchige, B.; Perinpanayagam, S.; Jaras, R. Enhanced prognostic model for lithium ion batteries based on particle filter state transition model modification. Appl. Sci. 2017, 7, 1172. [CrossRef]

77. Zhou, D.; Gao, F.; Breaz, E.; Ravey, A.; Miraoui, A. Degradation prediction of PEM fuel cell using a moving window based hybrid prognostic approach. Energy 2017, 138, 1175-1186. [CrossRef]

78. Chang, Y.; Fang, H.; Zhang, Y. A new hybrid method for the prediction of the remaining useful life of a lithium-ion battery. Appl. Energy 2017, 206, 1564-1578. [CrossRef]

79. Skima, H.; Medjaher, K.; Varnier, C.; Dedu, E.; Bourgeois, J. Microelectronics Reliability A hybrid prognostics approach for MEMS: From real measurements to remaining useful life estimation. Microelectron. Reliab. 2016, 65, 79-88. [CrossRef]

80. Wu, X.; Ye, Q.; Wang, J. A hybrid prognostic model applied to SOFC prognostics. Int. J. Hydrog. Energy 2017, 42, 25008-25020. [CrossRef]

81. Li, Z.; Wu, D.; Hu, C.; Terpenny, J. An ensemble learning-based prognostic approach with degradation-dependent weights for remaining useful life prediction. Reliab. Eng. Syst. Saf. 2018. [CrossRef]

82. Khalastchi, E.; Kalech, M.; Rokach, L. A hybrid approach for improving unsupervised fault detection for robotic systems. Expert Syst. Appl. 2017, 81, 372-383. [CrossRef]

83. Olivetti, E.A.; Ceder, G.; Gaustad, G.G.; Fu, X. Lithium-ion battery supply chain considerations: Analysis of potential bottlenecks in critical metals. Joule 2017, 1, 229-243. [CrossRef]

84. Xi, Z.; Zhao, X. Data driven prognostics with lack of training data sets. In Proceedings of the ASME 2015 International Design Engineering Technical Conferences \& Computers and Information in Engineering Conference, Boston, MA, USA, 2-5 August 2015. [CrossRef]

85. Medjaher, K.; Zerhouni, N.; Baklouti, J. Data-driven prognostics based on health indicator construction: Application to PRONOSTIA's data. In Proceedings of the 2013 European Control Conference (ECC), Zurich, Switzerland, 17-19 July 2013; pp. 1451-1456.

86. Orcioni, S.; Ricci, A.; Buccolini, L.; Scavongelli, C.; Conti, M. Effects of variability of the characteristics of single cell on the performance of a lithium-ion battery pack. In Proceedings of the 2017 13th Workshop on Intelligent Solutions in Embedded Sysems (WISES), Hamburg, Germany, 12-13 June 2017; pp. 15-21. [CrossRef]

87. Dey, S.; Perez, H.E.; Moura, S.J. Model-based battery thermal fault diagnostics: Algorithms, analysis, and experiments. IEEE Trans. Control Syst. Technol. 2017, 1-12. [CrossRef]

88. Ye, X.; Zhao, Y.; Quan, Z. Thermal management system of lithium-ion battery module based on micro heat pipe array. Int. J. Energy Res. 2017, 42, 648-655. [CrossRef]

89. Zhang, X.; Wang, Y.; Liu, C.; Chen, Z. A novel approach of remaining discharge energy prediction for large format lithium-ion battery pack. J. Power Sources 2017, 343, 216-225. [CrossRef]

90. Saxena, A.; Celaya, J.; Saha, B.; Saha, S.; Goebel, K. Metrics for offline evaluation of prognostic performance. Int. J. Progn. Health Manag. 2010, 1, 1-20. 
91. Sreejith, R.; Rajagopal, K.R. An insight into motor and battery selections for three-wheeler electric vehicle. In Proceedings of the 2016 IEEE 1st International Conference on Power Electronics, Intelligent Control and Energy Systems (ICPEICES), Delhi, India, 4-6 July 2016; pp. 9-14. [CrossRef]

92. Rizoug, N.; Sadoun, R.; Mesbahi, T.; Bartholumeus, P.; LeMoigne, P. Aging of high power Li-ion cells during real use of electric vehicles. IET Electr. Syst. Transp. 2017, 7, 14-22. [CrossRef]

93. Fotouhi, A.; Auger, D.J.; Propp, K.; Longo, S.; Purkayastha, R.; O’Neill, L.; Walus, S. Lithium-sulfur cell equivalent circuit network model parameterization and sensitivity Analysis. IEEE Trans. Veh. Technol. 2017, 66, 7711-7721. [CrossRef]

94. Wang, W.; Wu, Y. An overview of recycling and treatment of spent $\mathrm{LiFePO}_{4}$ batteries in China. Resour. Conserv. Recycl. 2017, 127, 233-243. [CrossRef]

95. Gong, Y.; Yu, Y.; Huang, K.; Hu, J.; Li, C. Evaluation of lithium-ion batteries through the simultaneous consideration of environmental, economic and electrochemical performance indicators. J. Clean. Prod. 2018, 170, 915-923. [CrossRef]

96. Amjad, S.; Neelakrishnan, S.; Rudramoorthy, R. Review of design considerations and technological challenges for successful development and deployment of plug-in hybrid electric vehicles. Renew. Sustain. Energy Rev. 2010, 14, 1104-1110. [CrossRef]

97. Martínez, D.A.; Poveda, J.D.; Montenegro, D. Li-Ion battery management system based in fuzzy logic for improving electric vehicle autonomy. In Proceedings of the 2017 IEEE Workshop on Power Electronics and Power Quality Applications (PEPQA), Bogota, Colombia, 31 May-2 June 2017. [CrossRef]

98. Berckmans, G.; Messagie, M.; Smekens, J.; Omar, N.; Vanhaverbeke, L.; van Mierlo, J. Cost projection of state of the art lithium-ion batteries for electric vehicles up to 2030. Energies 2017, 10, 1314. [CrossRef]

99. Badawy, M.O.; Sozer, Y. Power flow management of a grid tied PV-battery system for electric vehicles charging. IEEE Trans. Ind. Appl. 2017, 53, 1347-1357. [CrossRef]

100. Cazzola, P.; Gorner, M.; Yi, J.T.; Yi, W. Global EV Outlook 2016 Electric Vehicles Initiative. International Energy Agency. 2016. Available online: https://www.iea.org/publications/freepublications/.../Global_ EV_Outlook_2016.pdf (accessed on 10 February 2018).

101. Purwadi, A.; Shani, N.; Heryana, N.; Hardimasyar, T.; Firmansyah, M.; Sr, A. Modelling and analysis of electric vehicle DC fast charging infrastructure based on PSIM. In Proceedings of the 2013 1st International Conference on Artificial Intelligence, Modelling and Simulation, Kota Kinabalu, Malaysia, 3-5 December 2013; pp. 359-364. [CrossRef]

102. Saw, L.H.; Tay, A.A.O.; Zhang, L.W. Thermal management of lithium-ion battery pack with liquid cooling. In Proceedings of the 2015 31st Thermal Measurement, Modeling \& Management Symposium (SEMI-THERM), San Jose, CA, USA, 15-19 March 2015; pp. 298-302. [CrossRef]

103. Petroff, A. These Countries Want to Ditch Gas and Diesel Cars-26 July 2017. CNNMoney, 11 September 2017. Available online: http:/ / money.cnn.com/2017/07/26/autos/countries-that-are-banning-gas-cars-for-electric/ index.html (accessed on 4 February 2018).

104. Wang, M.M.; Zhang, C.C.; Zhang, F.S. Recycling of spent lithium-ion battery with polyvinyl chloride by mechanochemical process. Waste Manag. 2017, 67, 232-239. [CrossRef] [PubMed]

105. Chen, X.; Ma, H.; Luo, C.; Zhou, T. Recovery of valuable metals from waste cathode materials of spent lithium-ion batteries using mild phosphoric acid. J. Hazard. Mater. 2017, 326, 77-86. [CrossRef] [PubMed]

106. Boyden, A.; Soo, V.K.; Doolan, M. The environmental impacts of recycling portable lithium-ion batteries. Procedia CIRP 2016, 48, 188-193. [CrossRef]

107. Fan, B.; Chen, X.; Zhou, T.; Zhang, J.; Xu, B. A sustainable process for the recovery of valuable metals from spent lithium-ion batteries. Waste Manag. Res. 2016, 34, 474-481. [CrossRef] [PubMed]

108. Dewulf, J.; Van der Vorst, G.; Denturck, K.; Van Langenhove, H.; Ghyoot, W.; Tytgat, J.; Vandeputte, K. Recycling rechargeable lithium ion batteries: Critical analysis of natural resource savings. Resour. Conserv. Recycl. 2010, 54, 229-234. [CrossRef]

109. Sovacool, B.K.; Axsen, J.; Kempton, W. The future promise of Vehicle-to-Grid (V2G) integration: A sociotechnical review and research agenda. Annu. Rev. Environ. Resour. 2017, 42, 377-406. [CrossRef]

110. OECD/IEA. World Energy Outlook 2017 Executive Summary. International Energy Agency, 2017. Available online: http:/ / www.iea.org/publications/freepublications/publication/world-energy-outlook2017---executive-summary---english-version.html (accessed on 7 February 2018). 
111. Helbig, C.; Bradshaw, A.M.; Wietschel, L.; Thorenz, A.; Tuma, A. Supply risks associated with lithium-ion battery materials. J. Clean. Prod. 2018, 172, 274-286. [CrossRef]

112. Fathabadi, H. Plug-in Hybrid Electric Vehicles (PHEVs): Replacing Internal Combustion Engine with Clean and Renewable Energy Based Auxiliary Power Sources. IEEE Trans. Power Electron. 2018. [CrossRef]

113. Grunditz, E.A.; Thiringer, T. Performance analysis of current BEVs based on a comprehensive review of specifications. IEEE Trans. Transp. Electrification 2016, 2, 270-289. [CrossRef]

114. Bashash, S.; Moura, S.J.; Fathy, H.K. Charge trajectory optimization of plug-in hybrid electric vehicles for energy cost reduction and battery health enhancement. In Proceedings of the 2010 American Control Conference, Baltimore, MD, USA, 30 June-2 July 2010. [CrossRef]

115. Wang, Q.; Liu, W.; Yuan, X.; Tang, H.; Tang, Y.; Wang, M.; Zuo, J.; Song, Z.; Sun, J. Environmental impact analysis and process optimization of batteries based on life cycle assessment. J. Clean. Prod. 2018, 174, 1262-1273. [CrossRef]

116. Hatzell, K.B.; Sharma, A.; Fathy, H.K. A survey of long-term health modeling, estimation, and control of Lithium-ion batteries: Challenges and opportunities. In Proceedings of the 2012 American Control Conference (ACC), Montreal, QC, Canada, 27-29 June 2012; pp. 584-591.

117. Berecibar, M.; Gandiaga, I.; Villarreal, I.; Omar, N.; van Mierlo, J.; van den Bossche, P. Critical review of state of health estimation methods of Li-ion batteries for real applications. Renew. Sustain. Energy Rev. 2016, 56, 572-587. [CrossRef]

118. Winslow, K.M.; Laux, S.J.; Townsend, T.G. A review on the growing concern and potential management strategies of waste lithium-ion batteries. Resour. Conserv. Recycl. 2018, 129, 263-277. [CrossRef]

119. Kong, Q.; Ruan, M.; Zi, Y. A health management system for marine cell group. IOP Conf. Ser. Earth Environ. Sci. 2017, 69, 012081. [CrossRef]

120. Hu, J.; Zhang, J.; Li, H.; Chen, Y.; Wang, C. A promising approach for the recovery of high value-added metals from spent lithium-ion batteries. J. Power Sources 2017, 351, 192-199. [CrossRef]

121. Peng, X.; Garg, A.; Zhang, J.; Shui, L. Thermal management system design for batteries packs of electric vehicles: A Survey. In Proceedings of the 2017 Asian Conference on Energy, Power and Transportation Electrification (ACEPT), Singapore, 24-26 October 2017; pp. 1-5. [CrossRef]

(C) 2018 by the authors. Licensee MDPI, Basel, Switzerland. This article is an open access article distributed under the terms and conditions of the Creative Commons Attribution (CC BY) license (http://creativecommons.org/licenses/by/4.0/). 